\title{
AngiomiRs: MicroRNAs driving angiogenesis in cancer (Review)
}

\author{
YARELY M. SALINAS-VERA ${ }^{1}$, LAURENCE A. MARCHAT ${ }^{2}$, \\ DOLORES GALLARDO-RINCÓN ${ }^{3}$, ERIKA RUIZ-GARCÍA ${ }^{3}$, HORACIO ASTUDILLO-DE LA VEGA ${ }^{4}$, \\ RAQUEL ECHAVARRÍA-ZEPEDA ${ }^{5}$ and CÉSAR LÓPEZ-CAMARILLO ${ }^{1}$
}

\author{
${ }^{1}$ Posgrado en Ciencias Genomicas, Universidad Autonoma de la Ciudad de Mexico, Ciudad de Mexico 03100; \\ ${ }^{2}$ Programa en Biomedicina Molecular y Red de Biotecnologia, Instituto Politecnico Nacional, Ciudad de Mexico 07320; \\ ${ }^{3}$ Laboratorio de Medicina Translacional, Instituto Nacional de Cancerología, Ciudad de Mexico 14080; \\ ${ }^{4}$ Laboratorio de Investigacion Translacional en Cáncer y Terapia Celular, Hospital de Oncologia, \\ Centro Médico Nacional Siglo XXI, Ciudad de Mexico 06720; ${ }^{5}$ Catedratico CONACYT, \\ Instituto Politécnico Nacional, Ciudad de Mexico 11350, Mexico
}

Received June 14, 2018; Accepted October 22, 2018

DOI: $10.3892 /$ ijmm.2018.4003

\begin{abstract}
Angiogenesis is an important hallmark of cancer serving a key role in tumor growth and metastasis. Therefore, tumor angiogenesis has become an attractive target for development of novel drug therapies. An increased amount of anti-angiogenic compounds is currently in preclinical and clinical development for personalized therapies. However, resistance to current angiogenesis inhibitors is emerging, indicating that there is a need to identify novel anti-angiogenic agents. In the last decade, the field of microRNA biology has exploded revealing unsuspected functions in tumor angiogenesis. These small non-coding RNAs, which have been dubbed as angiomiRs, may target regulatory molecules driving angiogenesis, such as cytokines, metalloproteinases and growth factors, including vascular endothelial growth factor, platelet-derived growth factor, fibroblast growth factor, epidermal growth factor, hypoxia inducible factor-1, as well as mitogen-activated protein kinase, phosphoinositide 3-kinase and transforming growth factor signaling pathways. The present review discusses the current progress towards understanding the functions of miRNAs in tumor angiogenesis regulation in diverse types of human cancer. Furthermore, the potential clinical application of angiomiRs towards anti-angiogenic tumor therapy was explored.
\end{abstract}

Correspondence to: Dr César López-Camarillo, Posgrado en Ciencias Genomicas, Universidad Autonoma de la Ciudad de Mexico, San Lorenzo 290, Colonia del Valle, Ciudad de Mexico 03100, Mexico

E-mail: genomicas@yahoo.com.mx

Key words: cancer, microRNAs, angiogenesis, tumor neovascularization, therapy

\section{Contents}

1. Introduction

2. Biogenesis and processing of microRNAs

3. AngiomiRs: microRNAs modulating angiogenesis in human cancers

4. Clinical applications of angiomiRs in cancer therapy

5. Conclusions

\section{Introduction}

Angiogenesis is a complex cellular mechanism required for the formation of new blood vessels from the existing vasculature or from bone marrow-derived endothelial progenitors, allowing tumor growth and development at early stages of carcinogenesis (1). Neovascularization is a prerequisite for tumorigenesis when oxygen and nutrient levels are insufficient to sustain cell proliferation and tumor growth. During neovascularization, the tumor microenvironment produces stimulatory signals that induce changes in diverse cell types (Fig. 1). Pericytes detach from pre-existing vasculature disrupting the integrity of mature blood vessels. Platelets are activated and release stores of stimulatory factors into the tumor microenvironment. In addition, new vascular branches may be stimulated by bone marrow-derived endothelial progenitor cells (EPCs). Tumor cells also participate in the formation of new vessels through vascular mimicry, a novel angiogenesis-independent mechanism in which highly aggressive and metastatic epithelial tumor cells form vascular 3D channel-like structures resembling classical endothelial blood vessels (2). All these cellular types secrete soluble factors in the tumor microenvironment enhancing extracellular matrix (ECM) remodeling and inducing the production of tortuous blood vessels (neovascularization). Notably, this environment makes the tumor cells more invasive, allowing them to intravasate into the vasculature and to disseminate to distant tissues, resulting in metastasis.

The angiogenic switch that governs the tumor neovascularization requires a change in the balance between 
pro- and anti-angiogenic factors. Hypoxia is an important factor required for activation of the angiogenesis program, as it activates the expression of pro-angiogenic proteins from tumor and stroma cells, such as vascular endothelial growth factor (VEGF), transforming growth factor (TGF) $\alpha$, fibroblast growth factor (FGF), and platelet-derived growth factor (PDGF) among others. Hypoxia inducible factor 1 (HIF1) acts a master regulator of the genetic program leading to angiogenesis, mainly through activation of VEGF. The HIF1 protein complex is a heterodimer consisting of the HIF1 $\alpha$ and HIF $1 \beta$ subunits (3). Under normoxia conditions, HIF1 $\alpha$ is rapidly hydroxylated on conserved prolyl residues located within the oxygen-dependent degradation domain, and then it binds to von Hippel-Lindau protein (pVHL), which in turn targets HIF-1 $\alpha$ for degradation through the ubiquitin-proteasome pathway. By contrast, hypoxia inhibits the hydroxylation of HIF1 $\alpha$ prolyl residues 402 and 564, which in turn inhibits both binding to pVHL and protein degradation. The HIF1 complex recognizes and binds to the hypoxia response sequence element (5'-CGTG-3') on the promoter regions of pro-angiogenic genes, such as VEGF, PDGF, and TGF- $\alpha$, activating them and resulting in blood vessel remodeling and angiogenesis. In addition, growth factors, cytokines and oncogenes, which stimulate the mitogen-activated protein kinase (MAPK) and phosphoinositide 3-kinase (PI3K) pathways, enhance HIF-1 $\alpha$ activity. Notably, the genes responsible for the angiogenic switch may be regulated at the post-transcriptional level by microRNAs (miRNAs). Understanding the role of miRNAs is particularly relevant in aberrant angiogenesis in human cancers. Thus, the crucial role of neovascularization to tumor progression has rendered angiogenesis a particularly interesting research field of drug development, as it provides opportunities for clinical intervention.

\section{Biogenesis and processing of microRNAs}

miRNAs are conserved small non-coding RNAs of 21-25 nucleotides in length, which act as negative regulators of gene expression. The canonical biogenesis of miRNAs initiates with transcription of genes located in intergenic regions by RNA polymerase II (RNA pol II) to generate hairpin-shaped long transcripts, called primary miRNAs (pri-miRNA), with 5'-cap and 3'-end poly(A) tail (4). Subsequently, these molecules are recognized by the DiGeorge syndrome critical region protein 8 (DGCR8) which associates with the RNAse III enzyme Drosha in a microprocessor complex that cleaves pri-miRNA and liberates stem-loop structures, known as precursor miRNAs (pre-miRNA) (5). Alternatively, pre-miRNAs can be generated by the mRNA splicing machinery from introns or pseudo-genes, without the participation of the microprocessor complex (6). Pre-miRNA molecules have a 3' end two-nucleotide overhang that is recognized by the Ran-GTP dependent export factor exportin 5 that facilitates their translocation to the cytoplasm. In this cellular compartment, the RNAse III enzyme Dicer interacting with the double-stranded (ds) RNA-binding protein TRBP2 eliminates the loop, to produce an imperfect dsRNA duplex. Although the transient strand miRNA* has previously been considered as irrelevant, recent studies suggest that it is as functional as the guide strand. These 19-25 bp RNA molecules, together with Argonaute proteins, can be incorporated into the silencing complex induced by RNA-induced silencing complex (RISC), to promote recognition of the complementary sequence; predominantly in the 3' untranslated region (3'-UTR) of target mRNAs (7). The fate of targeted transcripts depends on the degree of complementarity between miRNA and mRNA. A perfect interaction leads to messenger degradation, while imperfect complementary binding induces translational repression (8). Both events occur in cytoplasmic foci denoted as mRNA processing bodies (P-bodies), which represent mRNA processing centers where non-translating transcripts are stored, silenced or degraded (9).

\section{AngiomiRs: microRNAs modulating angiogenesis in human cancers}

Altered expression of miRNAs has been reported in diverse types of human cancer, where they regulate the expression of oncogenes and tumor suppressor genes, thus they have been dubbed as oncomiRs. In many cases, aberrant expression of miRNAs correlates with worst prognosis, low overall survival and resistance to chemotherapy (10). Diverse studies, focused on miRNA profiles impacting angiogenesis, have been described in almost all human cancers $(11,12)$. miRNAs controlling the angiogenic mechanisms are collectively known as angiomiRs, as they regulate this specialized process in both physiological and pathological conditions (Fig. 2 and Table I) $(13,14)$. The biological relevance of miRNAs in angiogenesis was first uncovered by loss of function studies in which Dicer, an endonuclease required for miRNA maturation, was disrupted. Generation of Dicer1-deficient mice resulted in early embryonic lethality and stem cell loss (15). In addition, mice carrying a deletion corresponding to the first and second exons of the Dicer gene exhibited severe vascular defects and had altered expression of angiogenic regulators (16). Since complete abrogation of Dicer in mice was embryonic lethal, the specific role of miRNAs in angiogenesis was addressed by generating endothelial-specific Dicer knockouts (17). The cell-specific inactivation of Dicer resulted in the reduction of endothelial miRNAs and reduced postnatal angiogenic response to exogenous VEGF, tumors, limb ischemia, and wound healing. Furthermore, VEGF regulated the expression of oncogenic miRNAs of the cluster miR-17-92. These data indicated that endothelial miRNAs regulate postnatal angiogenesis and VEGF upregulated the expression of miRNAs implicated in the angiogenic response. Different laboratories have also demonstrated that silencing Dicer in epithelial cells inhibits cell proliferation, migration, and capillary sprouting under basal conditions and in response to angiogenic factors $(18,19)$. According to Kuehbacher et al (18), depleting Dicer and Drosha using siRNAs in endothelial cells reduced lef-7f and mir-27b expression. In addition, inhibitors of let-7f and mir-27b reduced sprout formation indicating that let- $7 \mathrm{f}$ and mir-27b promote angiogenesis by targeting antiangiogenic genes (18). By contrast, the knockdown of Dicer in endothelial cells also altered the expression of regulators of angiogenesis, including TEK receptor tyrosine kinase (also known as Tie2), VEGFR2, Tie1, endothelial nitric oxide synthase and interleukin (IL) 8. The global profiling of miRNAs revealed 25 upregulated miRNAs in endothelial cells and using miRNA mimicry, miR-222/221 regulated nitric oxide synthase 


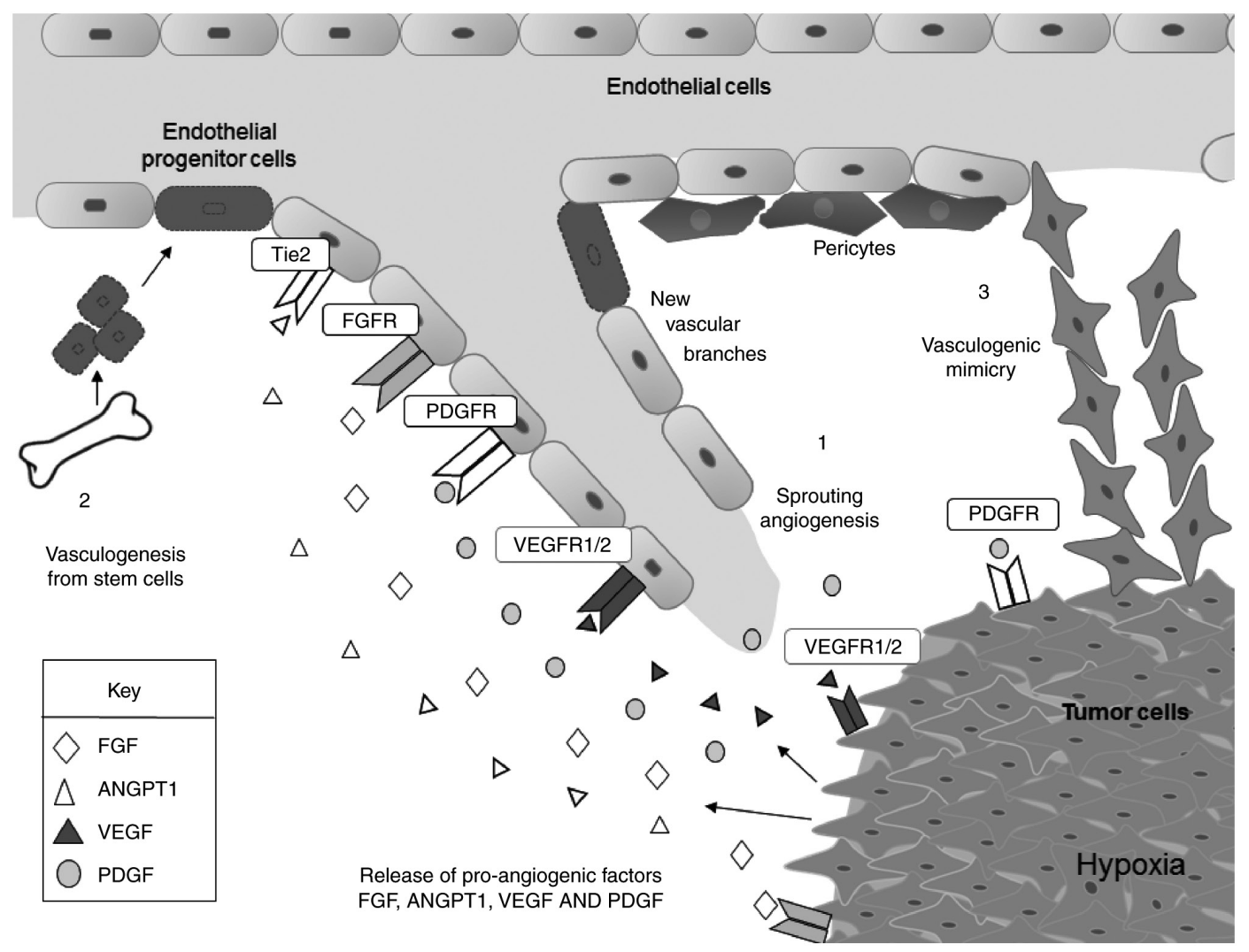

Figure 1. Overview of the mechanisms of angiogenesis. The three different mechanisms of angiogenesis are illustrated: (1) sprouting angiogenesis, (2) vasculogenesis de novo from stem cells, and (3) vascular mimicry. The release of pro-angiogenic factors from tumor cells interacting with their cognate receptors is indicated in the plasmatic membrane of endothelial cells (paracrine regulation) and tumor cells (autocrine regulation). FGF, fibroblast growth factor; ANGPT1, angiopoietin 1; VEGF, vascular endothelial growth factor; PDGF, platelet-derived growth factor; R, receptor; Tie2, TEK receptor tyrosine kinase.

following Dicer silencing (19). Although these studies support the idea of miRNAs controlling vascular function and angiogenesis, the contribution of additional non-canonical functions of Dicer to the angiogenic process cannot be excluded.

Further support for a role of miRNAs in the vasculature came from studies that identified endothelial miRNAs using microarrays (20-23). An early report identified 27 miRNAs highly expressed in human umbilical vein endothelial cells (HUVECs), many of which had angiogenic factor receptors as their predicted mRNA targets. Authors demonstrated that both miR-221 and miR-222 specifically regulate stem cell factor (SCF)-induced angiogenesis by targeting c-KIT (19). Likewise, McCall et al (22) described a miRNAs signature whose expression levels are generally consistent across epithelial cells form different vascular locations with the exception of miR-99b, miR-20b and let-7b. To date, close to 200 endothelial miRNAs have been described, though $<20 \%$ of them have been consistently found across different studies (22). Endothelial miRNA expression profiles are also known to be modified in response to a wide array of stimuli including hypoxia, VEGF and angiotensin II, providing evidence of the plasticity of this system in fine-tuning vascular function. For instance, miR-126, miR-210 and the miR17/92 cluster, a polycistronic miRNA gene that encodes for miR-17, miR-18a, miR-19a, miR-20a, miR-19b-1 and miR-92a, are an example of miRNAs essential for maintaining vascular structure in vivo; but many more have emerged as regulators of endothelial cell survival, migration, proliferation and angiogenic signaling pathways $(22,23)$. Therefore, angiomiRs may be promising targets and they may contribute to anti-angiogenesis-based combined treatments of cancer (24).

AngiomiRs in breast cancer. Breast cancer is one of the most frequent carcinomas and ranks second as a cause of cancer-related mortality in women (25). Several research groups have identified distinct miRNA expression profiles and individual miRNAs relevant for angiogenesis, metastasis and overall survival in breast cancer patients. For instance, the endothelial miR-126, derived from the intron 7 of the EGF-like domain 7 (EGFL7) (26), was found downregulated in breast tumors and associated with poor overall metastasis-free survival (27). Zhu et al (28) demonstrated that miR-126 inhibits VEGF/PI3K/AKT signaling by targeting VEGFA and PI3K regulatory subunit 2 (PIK3R2). Ectopic expression of miR-126 suppressed the expression of CD97, a G-coupled receptor that promotes cell invasion and angiogenesis through integrin signaling (29). miR-126 and miR-126* both influence breast cancer metastasis by cell autonomous and non-cell autonomous mechanisms involving angiogenesis (30). Of note, miR-126/miR-126* also inhibited lung metastasis of breast cancer cells by suppressing the recruitment of mesenchymal stem cells and inflammatory monocytes into the tumor microenvironment in a stromal cell-derived factor $1 a$ (SDF1A)-dependent manner. Another study demonstrated that miR-126 regulates angiogenesis and metastasis by targeting the pro-angiogenic insulin-like growth factor binding protein 2 


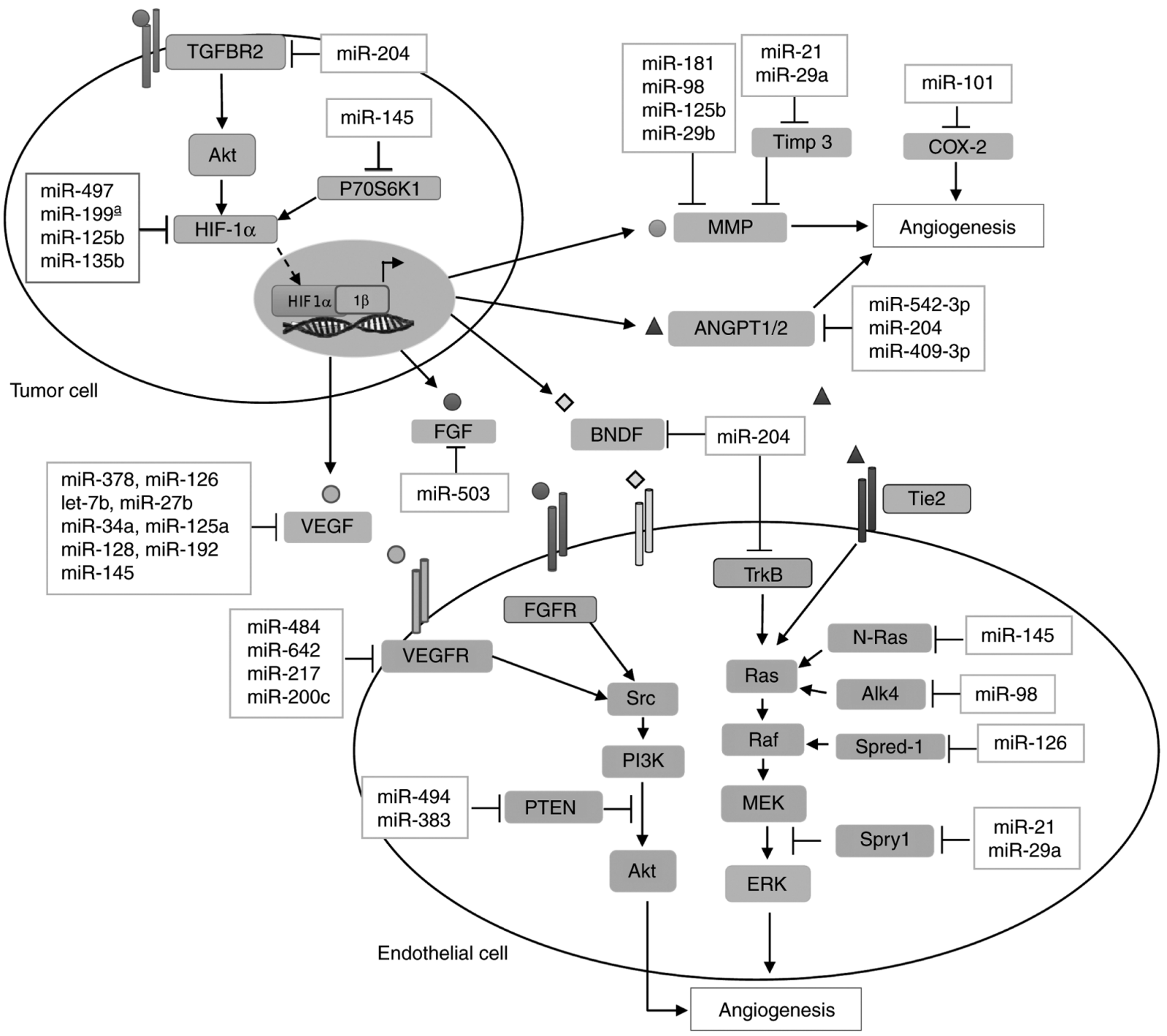

Figure 2. AngiomiRs and their targets in tumor and endothelial cells. The diagram illustrates the main genes and signaling pathways targeted by diverse angiomiRs deregulated in human tumors. TGFBR2, transforming growth factor $\beta$ receptor 2 ; HIF, hypoxia-inducible factor; Timp3, tissue inhibitor of metalloproteinases-3; COX-2, cyclooxygenase-2; MMP, matrix metallopeptidase; ANGPT, angiopoietin; BNDF, brain-derived neurotrophic factor; FGF, fibroblast growth factor; VEGF, vascular endothelial growth factor; R, receptor; Tie2, TEK receptor tyrosine kinase; TrkB, tropomyosin receptor kinase B; PI3K, phosphoinositide 3-kinase; PTEN, phosphatase and tensin homolog; MEK, mitogen-activated protein kinase kinase; ERK, extracellular signal-regulated kinase; Alk4, activin A receptor type 1B; Spred-1, sprouty related EVH1 domain containing 1; Spry1, sprout homolog 1.

(IGFBP2), phosphatidylinositol transfer protein cytoplasmic 1 and c-Mer tyrosine kinase genes (31).

On the other hand, miR-497 reduces tumor growth and angiogenesis in a mouse xenograft model (32). In addition, conditioned media derived from miR-497-expressing cells, suppress endothelial cell tube formation in vitro and reduce VEGF and HIF1 $\alpha$ protein levels. Tu et al (33) reported that overexpression of miR-497 in 4T1 cells significantly inhibited breast tumor growth, angiogenesis and VEGFR2 expression when subcutaneously implanted in VEGFR2-luc transgenic mice. In addition, miR-497 expression in HUVECs induces apoptosis and inhibits cell proliferation by targeting AKT and extracellular signal-regulated kinase (ERK) signaling pathways in a VEGFR2-dependent way.

Tumors respond to low oxygen tension by activation of HIF1 $\alpha$-dependent and hypoxia-induced genetic program involving miRNAs (34). For instance, recent studies reported that miR-155, miR-578 and miR-573 have key roles in
HIFl $\alpha$-mediated angiogenesis, and their expression was differentially modulated in BRCA1/2-related breast cancer $(35,36)$. Kong et al (37) demonstrated that miR-155 overexpression in tumor cells promotes angiogenesis, proliferation and proinflammatory cell recruitment in a mammary fat pad xenotransplant model. In addition, miR-155 levels are inversely correlated with von Hippel-Lindau (VHL), an E3 ubiquitin ligase that targets HIF1 family members; this finding suggests that miR-155 expression decreases HIF1 $\alpha$-mediated angiogenesis by targeting VHL in breast tumors. By contrast, miR-578 and miR-573 are downregulated in BRCA1/2-related breast cancer and appear to control angiogenesis by modifying VEGFA, focal adhesion kinase (FAK), angiopoietin 2 (ANGPT2) and HIF1 $\alpha$ expression through an indirect mechanism, since they failed to bind to the 3' UTR of the aforementioned genes (38). Additionally, miR-210, a hypoxia-inducible miRNA, is involved in tumor growth, angiogenesis and activation of VEGF signaling in breast cancer patients (39). 
Table I. microRNAs and gene targets involved in angiogenesis in diverse types of cancer.

\begin{tabular}{|c|c|c|c|}
\hline Author, year & microRNA & Gene targets & (Refs.) \\
\hline $\begin{array}{l}\text { Meister et al, 2010; } \\
\text { Zhu et al, 2011; Lu et al, 2014; } \\
\text { Png et al, 2011 }\end{array}$ & Breast cancer miR-126 & PIK3R2, VEGFA, CD97, IGFBP2 & $(27-29,31)$ \\
\hline $\begin{array}{l}\text { Wu et al, 2016; Tu et al, 2015; } \\
\text { Zhao et al, } 2013\end{array}$ & miR-497, miR-21 & HIF-1 $\alpha$, VEGF, VEGFR2 & $(32,33,41)$ \\
\hline Kong et al, 2016 & $\operatorname{miR}-155$ & VHL & (37) \\
\hline Kong et al, 2014 & miR-57, miR-573 & VEGFA, FAK, ANGPT2, HIF- $1 \alpha$ & (38) \\
\hline $\begin{array}{l}\text { Mathsyaraja et al, 2015; } \\
\text { He et al, 2014; He et al, } 2015\end{array}$ & $\operatorname{miR}-542-3 p$ & Angiopoietin-2, CEBPB, POU2F1 & $(42-44)$ \\
\hline $\begin{array}{l}\text { Flores-Pérez et al, 2016; } \\
\text { Salinas-Vera et al, } 2018\end{array}$ & $\operatorname{miR}-204$ & ANGPT1, TGFBR2, PI3K, Src & $(47,48)$ \\
\hline $\begin{array}{l}\text { Kadera et al, 2013; } \\
\text { Chan } \text { et al, } 2012\end{array}$ & $\begin{array}{l}\text { Pancreatic cancer miR-21, } \\
\text { miR-199 }\end{array}$ & HIF-1 $\alpha$, VEGF & $(59,62)$ \\
\hline Zhao et al, 2010 & $\operatorname{miR}-34 a$ & SIRT1 & (68) \\
\hline Liu et al, 2009 & $\begin{array}{l}\text { Lung cancer miR-126, } \\
\text { let-7b }\end{array}$ & VEGFA & (75) \\
\hline Tejero et al, 2014 & $\operatorname{miR}-128$ & VEGFC & (82) \\
\hline Mao et al, 2015 & $\operatorname{miR}-494$ & PTEN & (86) \\
\hline Pesta et al, 2011 & $\begin{array}{l}\text { miR-210 } \\
\text { Colorectal cancer }\end{array}$ & VEGFR2 & (93) \\
\hline $\begin{array}{l}\text { Zhang et al, 2013; } \\
\text { Hansen et al, 2011; } \\
\text { Hansen et al, } 2013\end{array}$ & miR-126 & VEGF, VEGFR2 & $(97-99)$ \\
\hline Nagao et al, 2012 & $\operatorname{miR}-21$ & PTEN, TIMP3, TPM1 & (103) \\
\hline Bridge et al, 2012 & $\operatorname{miR}-30$ & DLL4 & (105) \\
\hline Amodeo et al, 2013 & miR-18a, miR-19 & EGR1 & (110) \\
\hline $\begin{array}{l}\text { Sundaram et al, 2011; } \\
\text { Braun et al, } 2008\end{array}$ & miR-194 & $\mathrm{p} 53$ & $(112,113)$ \\
\hline Dai et al, 2016; Fang et al, 2016 & $\operatorname{miR}-15-16$ & FGF2, CCNB1 & $(115,116)$ \\
\hline $\begin{array}{l}\text { Wang et al, 2014; } \\
\text { Subramanian et al, 2014; } \\
\text { Colangelo et al, } 2013\end{array}$ & $\operatorname{miR}-29 b$ & $\begin{array}{l}\text { TCF7L2, SNAIL, BCL9L, } \\
\text { MMP2, TIAM1 }\end{array}$ & $(118,119,121)$ \\
\hline $\begin{array}{l}\text { Urbich et al, 2012; } \\
\text { Veliceasa et al, 2015; } \\
\text { Bao et al, } 2014\end{array}$ & $\operatorname{miR}-27 a$, miR-27b & DLL4, SPRY2, VEGFC, SGPP1, SMAD2 & $(123,124,128)$ \\
\hline Geng et al, 2014 & miR-192 & BCL2, ZEB2, VEGFA & $(130)$ \\
\hline Yin et al, 2013; Xu et al, 2012 & $\operatorname{miR}-145$ & AKT, N-RAS, IRS1,VEGF, p70S6K1 & $(131,132)$ \\
\hline Qian et al, 2013 & $\operatorname{miR}-143$ & AKT, HIF-1 $\alpha$, VEGF & (134) \\
\hline Zhang et al, 2011 & $\begin{array}{l}\text { miR-23b } \\
\text { Ovarian cancer }\end{array}$ & 7FZD7, MAP3K1 & (135) \\
\hline Xu et al, 2012; He et al, 2013 & $\begin{array}{l}\operatorname{miR}-199 a, \operatorname{miR}-125 b \\
\text { miR-145 }\end{array}$ & HIF-1 $\alpha$, VEGF, p70S6K & $(132,142)$ \\
\hline $\begin{array}{l}\text { Vecchione et al, 2013; } \\
\text { Lai et al, } 2013\end{array}$ & $\begin{array}{l}\operatorname{miR}-484, \operatorname{miR}-642, \\
\operatorname{miR}-217, \operatorname{miR}-27 a\end{array}$ & VEGF, VEGFR2, COX2, SP1 & $(11,145)$ \\
\hline Korpal et al, 2008; Pecot et al, 2013 & miR-200 family & ZEB1, ZEB2, IL8, CXCL1 & $(146,147)$ \\
\hline Imam et al, 2012 & miR-204 & BDNF & (148) \\
\hline
\end{tabular}

miR, microRNA. 
Oncogenic miR-21 has been identified as a potential molecular prognostic marker for breast cancer progression, as its overexpression correlates with advanced tumor stage, lymph node metastasis and poor patient survival (40). In a VEGFR2-luc mouse model of breast tumorigenesis, a miR-21 antagomir effectively suppressed tumor growth and angiogenesis by targeting the VEGF/VEGFR2/HIF1 $\alpha$ axis (41). Notably, miR-21 and miR-29a expression in macrophages promoted $\mathrm{CD} 31^{+}$vessel growth in matrigel plugs and reduced the expression of anti-angiogenic genes, such as collagen type IV $\alpha 2$ (COL4A2), sprouty homolog 1 (SPRY1) and tissue inhibitor of metalloproteinases-3 (TIMP3). These findings suggest that miR-21 and miR-29a facilitate a pro-angiogenic phenotype in tumor-associated myeloid cells, which contributes to tumor progression (42). In addition, key modulators of angiogenesis and extracellular matrix remodeling, like VEGFA, angiopoietin-like 4, PDGF, lysyl oxidase (LOX), metallopeptidase (MMP) 2 and MMP9, contain functional miR-29b-specific binding sites located in their $3^{\prime}$ UTRs, suggesting that miR-29b may act as a multi-target non-coding RNA to suppress metastasis of cancer cells.

miR-542-3p levels inversely correlate with clinical progression of breast cancer in patients with advanced stage disease (43). Ectopic expression of miR-542-3p reduced tumor growth, angiogenesis and metastasis in a breast cancer mouse model (44). He et al (44) proposed a novel tumor-endothelial cell-signaling pathway to explain the angiogenic inhibition induced by miR-542-3p. In their model, tumor cell-derived angiogenin was demonstrated to downregulate miR-542-3p in endothelial cells by suppressing the CCAAT/enhancer-binding protein $\beta(\mathrm{CEBP} \beta)$ and POU class 2 homeobox 1 (POU2F1) transcription factors, while increasing the expression of ANGPT2 protein (44).

miR-568 has been reported as a circulating breast cancer-specific miRNA (45). miR-568 expression was low in metastatic breast cancer cells as a result of epigenetic silencing by the non-coding IncRNA Hotair, a known promoter of metastasis in various human cancers, which alters gene expression profiles through chromosomal silencing (46). Evidence suggests that low miR-568 results in a more sustained expression of its target nuclear factor of activated T-cells 5 (NFAT5), a pro-angiogenic and metastatic transcriptional activator of VEGFC and S100A4 proteins (46).

miR-204 is a novel multi-target angiomiR in breast cancer. Recently, we analyzed the miRNome of locally advanced breast tumors and found a consistent and dramatic suppression of miR-204 in patient tumors and breast cancer cell lines (47). Ectopic expression of miR-204 inhibited cell proliferation, anchorage-independent growth, migration, and invasion. In vivo vascularization and angiogenesis were also suppressed by miR-204 in a nu/nu mice model. Transcriptome profiling of MDA-MB-231 cells expressing miR-204 indicated that expression of pro-angiogenic ANGPT1 and TGF $\beta R 2$ proteins was suppressed by miR-204. Functional analysis confirmed that ANGPT1 and TGF $\beta$ R2 are novel targets of miR-204. In agreement, an inverse correlation between miR-204 and ANGPT1/TGF $\beta$ R2 expression was evidenced in breast tumors, revealing a novel role for the miR-204/ANGPT1/TGFßR2 axis in tumor angiogenesis (47). Recently, our group also reported that miR-204 has a pivotal role in the formation of 3D capillary-like networks by tumor cells, a cellular mechanism denoted as vasculogenic mimicry (VM) in cancer cells. This phenomenon was first described in melanoma cells as a novel blood and oxygen supply event in which tumors can feed themselves. Of note, VM operates simultaneously with angiogenesis. During VM, tumor cells form patterned 3D channel-like structures which combine with blood vessels (mosaic pattern), challenging the initial assumption that angiogenesis is the only mechanism by which tumors acquire nutrients and oxygen. These pseudo-3D channels contain plasm, erythrocytes and blood flow with a hemodynamics resembling angiogenesis (48). miR-204 targets multiple signaling transducers involved in VM and angiogenesis in invasive triple negative MDA-MB-231 and $\mathrm{Hs}-578 \mathrm{~T}$ breast cancer cells. Ectopic restoration of miR-204 in MDA-MB-231 cells leads to a potent inhibition of hypoxia-induced VM and reduction of number of branch points and capillary tubes (49). Finally, miR-204 reduces the expression and phosphorylation of 13 proteins involved in PI3K/AKT, RAF1/MAPK, VEGF, and FAK/SRC signaling. Functional studies confirmed that miR-204 targets PI3Ka and c-SRC transducers, indicating that miR-204 exerts a fine-tuning regulation of the PI3K/AKT/FAK axis critical in VM formation and angiogenesis (49).

AngiomiRs in pancreatic cancer. Pancreatic cancer represents the fourth leading cause of cancer-related deaths in the United States, and with a 5-year survival rate of only 7\%, it has the worst outcome for cancer patients (50). Pancreatic ductal adenocarcinomas (PDACs) arise from the exocrine pancreas, represent $75 \%$ of pancreatic tumors, and are usually diagnosed at advanced stages (51). The vasculature of these tumors appears to be highly disorganized and hypoxic as a result of a characteristic desmoplasia, in which excessive proliferation of activated fibroblasts and overproduction of extracellular matrix proteins increase interstitial pressure and cause vascular disruption (52). Hypoxia-associated angiomiRs, such as miR-21, miR-200c and miR-199, are known to be dysregulated in PDACs (53). Hypoxia promotes pancreatic cancer cell migration, invasion and angiogenesis in vitro, and also induces miR-21 expression (54). miR-21 overexpression has been reported in pancreatic carcinoma cell lines and tumors (55-57). Clinical studies have associated miR-21 with poor clinical outcomes and resistance to chemotherapy; miR-21 plasma levels also seem to correlate with advanced stage, metastasis and shorter survival in patients with PDAC (57). Bao et al (58) recently reported that transfection of a miR-21 antagomiR resulted in an increase of phosphatase and tensin homolog (PTEN) expression in pancreatic cancer cells, a potent suppression of AKT and ERK signaling pathways, and a reduction of angiogenesis, as a result of HIF1 $\alpha$ and VEGF downregulation. Pancreatic cancer cells induce tumor-associated fibroblasts to express miR-21 as a mechanism to enhance their own invasiveness; and higher expression of stromal miR-21 correlates with metastasis in PDAC patients (59). Increased levels of HIF1 $\alpha$ are associated with advanced tumor stages in PDAC patients (60). Notably, a HIF-1 $\alpha$ single-nucleotide polymorphism (SNPs), rs2057482, was reported as an important genetic variant for PDAC risk and poor prognosis (61). This SNP was located near the 
miR-199a seed-binding site in the 3' UTR of HIF1 $\alpha$; and the presence of a CC genotype decreased miR-199a-induced repression of HIF-1 $\alpha$. Although the specific role of miR-199a in PDAC vasculature is unknown, miR-199a modulates the ETS-1/MMP1 pathway in ECs and has been described as an important regulator of angiogenic processes (62).

Loss of function of tumor suppressor p53 occurs in 50-75\% of PDACs (63). miR-34a is a direct transcriptional target of $\mathrm{p} 53$, whose expression is altered in pancreatic cancer $(64,65)$. The epigenetic inactivation of miR-34a by $\mathrm{CpG}$ methylation is a common event during tumor progression (65). An analysis on the methylation status of the miR-34a gene revealed that, in $64 \%$ of the pancreatic tumors studied, miR-34a was methylated, suggesting that miR-34a CpG methylation could be an alternative mechanism to $\mathrm{p} 53$ inactivation in PDAC progression (66). Of note, miR-34a has been demonstrated to regulate genes involved in angiogenesis, cell-cycle progression, cellular proliferation, apoptosis and DNA repair (67). Additionally, miR-34a expression impairs endothelial progenitor cell (EPC)-mediated angiogenesis by repressing its target, silent information regulator 1 (SIRT1), which induces senescence (68). Further studies are needed to understand the role of miR-34a in the regulation of angiogenesis in PDAC.

AngiomiRs in lung cancer. Lung cancer represents the first cause of cancer-related mortality in men and women. Approximately $80 \%$ of lung tumors are non-small cell lung cancer (NSCLC) (69). Angiogenic factors are prognostic indicators for tumor aggressiveness and survival in NSCLC, and angiogenic inhibitors are currently being used as treatment with varying results (70-72). A recent study by Chen et al (73) highlighted the importance of miRNAs in the development and maintenance of tumor vasculature by subcutaneously injecting Dicer1 $^{-/-}$NSCLC cells into flanks of nude mice. Furthermore, several angiomiRs have been reported with altered expression levels in NSCLC, including miR-126, miR-21, miR-210, miR-106a, miR-155, miR-182 and miR-424 (74). For instance, several studies reported that miR-126 is downregulated in NSCLC tumors and lung cancer cell lines, and high miR-126 expression has been associated with lymph node status, poor survival and high VEGFA expression $(75,76)$. In addition, miR-126 emerged as part of an angiogenic signature in a cohort of 335 NSCLC patients (74). Liu et al (75), demonstrated that transducing miR-126 into A549 tumor cells using a lentiviral vector produces smaller tumor nodules through downregulation of its direct target VEGFA and cell arrest induction. A possible anti-angiogenic role of miR-126 and miRNA let-7b in lung cancer development was suggested by a study in which miR-126 and let-7b downregulation correlated with higher microvessel density (MVD) in tumor and surrounding stroma when compared to non-tumor tissues (77). Notably, members from the let-7 family are known players in hypoxia-induced angiogenesis and their downregulation has also been linked to poor survival outcomes of lung cancer patients (78-80).

$\mathrm{Hu}$ et al (81) reported that miR-128 expression was significantly reduced in NSCLC tissues and cancer cells, and correlated with NSCLC differentiation, pathological stage and lymph node metastasis. Restoring miR-128 expression in A549 cells inhibited angiogenesis, lymphangiogenesis and tumorigenicity in nude mice. These effects appear to be mediated by direct binding of miR-128 to the VEGFC 3'UTR, and by inhibiting the activation of ERK, AKT and p38 signaling pathways. miR-141 is another miRNA that indirectly modulates VEGFA levels in lung cancer cells through direct repression of its target Kruppel-like factor 6 (KLF6) (82). High levels of miR-141 also correlate with a higher number of blood vessels suggesting that miR-141 promotes angiogenesis in lung tumors.

Brain metastasis is common among NSCLC patients (83). Analysis of miRNAs expressed in NSCLC patients identified miR-378 as being differentially expressed in patients with or without brain metastasis (84). In vivo, miR-378 overexpressing tumors are larger, more vascularized and metastatic $(84,85)$.

Mao et al (86), reported a pro-angiogenic mechanism in which miR-494, secreted by lung cancer cells and delivered into ECs via microvesicles, increased EC migration and angiogenesis. miR-494 is induced by hypoxia and its inhibition with antagomiRs blocked angiogenesis and tumor growth in A549 xenografts. The angiogenic effect of miR-494 was demonstrated to be mediated by direct targeting of PTEN and subsequent activation of the AKT/eNOS pathway. miR-497 was also downregulated in NSCLC tumors and cell lines, and displayed an inverse correlation with its downstream target hepatoma-derived growth factor (HDGF) (87). In lung cancer cells, restoring miR-497 expression had profound effects on cell proliferation and colony formation resulting from HDGF modulation. Furthermore, ectopic expression of miR-497 in a mouse xenograft model significantly inhibited tumor growth and angiogenesis, highlighting its role as an angiomiR in lung cancer.

The cluster miR-132/212 is located within the same intron of a non-coding gene on human chromosome 17 , and its deletion increases angiogenic responses in vivo (88). miR-132 expression is significantly downregulated in NSCLC clinical specimens and cell lines, and miR-212 silencing is frequent in lung cancer and closely correlates with stage of disease in NSCLC patients $(89,90)$. A study by Luo et al (91) evaluated the effect of the miR-132/212 cluster in subcutaneous xenografts of human lung cancer H1299 cells in nude mice. The results demonstrated that miR-132/212 cluster expression inhibited tumor growth by increasing p21 expression, downregulating CyclinD1, and decreasing MVD. These findings propose an important role of miR-132 and miR-212 in tumor angiogenesis; however the exact mechanisms by which these miRNAs reduce MVD remain unknown.

Tissue inhibitor of metalloproteinases-1 (TIMP1) has emerged as a pro-angiogenic factor responsible for miR-210 upregulation in a CD63/PI3K/AKT/HIF1-dependent pathway in lung adenocarcinoma cells (92). Elevated TIMP-1 levels correlate with adverse prognosis in NSCLC patients (93). Cui et al (92) have reported that TIMP-1 overexpression in A549L cells increases angiogenesis in tumor xenografts, results in exosomal miR-210 accumulation, and promotes capillary tube formation in HUVECs. Additionally, fibroblast growth factor receptor-like 1 (FGFRL1), E2F transcription factor 3 (E2F3), vacuole membrane protein 1 (VMP1), Rad52 and succinate dehydrogenase complex subunit D (SDHD) are miR-210 downstream targets downregulated in the presence of TIMP-1, suggesting that the pro-tumorigenic functions of TIMP-1 are partly mediated by miR-210. 
AngiomiRs in colorectal cancer. Colorectal cancer (CRC) is the third most commonly diagnosed cancer (94). Several studies based on miRNAs profiling demonstrate that a large number of miRNAs are altered in this disease (95). In accordance with data from other tumors, miR-126 is downregulated in primary CRC tissues and cell lines (96). Increased promoter methylation of EGFL7, the miR-126 host gene, was proposed as the mechanism responsible for miR-126 downregulation in CRC cells (97). Restoration of miR-126 inhibited migration and invasion of CRC cells, and reduced angiogenesis by repressing VEGF. By contrast, high levels of miRNA-126 are associated with higher MVD accompanied with high VEGFR2 expression (98). In addition, high levels of miR-126 in CRC tumors were associated with increased progression-free survival of patients in a randomized phase III study (99).

Several studies have demonstrated that miR-21 is frequently overexpressed in serum and tumor tissues from CRC patients (100-102). Since miR-21 is a negative regulator of multiple tumor suppressor genes, including PTEN, TIMP3, TPM1, maspin and programmed cell death protein 4 (PCDP4), some research groups have focused on the effects of anti-miR-21 therapies in CRC (103). Silencing of miR-21 in CRC cells using miR-21 antagomiRs affected cell cycle and cell viability and activated apoptosis (104). In addition, anti-miR-21 treatment also inhibited capillary-like networks formation in vitro. Bridge et al (105) reported a functional role for miR-30 in the regulation of angiogenesis by targeting Delta-like 4 (DLL4), and demonstrated that introduction of exogenous miR-30 in ECs or into zebrafish embryos promoted angiogenic sprouting. DLL4 is a membrane-bound ligand from the Notch signaling family, restricted to tip cells, which regulates vessel sprouting and branching in response to angiogenic factors during vascular development and angiogenesis (106).

Thrombospondin 1 (TSP1), a protein mainly expressed in tumor stroma, inhibits angiogenesis and tumor growth via the TGF $\beta$ pathway in CRC (107). Several reports have suggested that miR-182 and miR-194 (miR-17-92 cluster) contribute to angiogenesis through a mechanism that represses TSP1 in CRC. The miR-17-92 cluster is upregulated in CRC and correlates with progression from colorectal adenoma to adenocarcinoma (108). According to Dews et al (109), K-RAS-transformed p53-null mouse colonocytes form poorly vascularized tumors, which were reverted to highly vascularized tumors with increased growth when transduced with a Myc-encoding retrovirus. Behind these Myc-dependent effects was the upregulation of miR-17-92 cluster, which appears to promote angiogenesis through direct repression of TSP1 and connective tissue growth factor (CTGF) by miR-18a and miR-19, respectively. In addition, miR-182 binds to the TSP1 3'UTR in CRC cells and decreases nuclear translocation of early growth response 1 (EGR1) (110). Expression of miR-194 is known to be gastrointestinal tract-specific and p53-dependent; loss of p53 in HCT116 cells significantly reduces miR-194 levels $(111,112)$. A study by Sundaram et al (112) described miR-194 as intrinsically angiogenic. Furthermore, transient overexpression of miR-194 in HCT116/THBS1 cells resulted in high angiogenesis in vitro. Likewise, stable expression of miR-194 in RAS-induced murine colon carcinomas, augmented MVD and vessel sizes. Notably, these pro-angiogenic effects of miR-194 in vivo did not translate into increased tumor growth, presumably due to regulation of other miR-194 targets and its co-expression with miR-215, a known inhibitor of the cell cycle $(112,113)$.

During hypoxia the miR-15-16 cluster is repressed by c-Myc, which results in elevated tumor angiogenesis and metastasis by inducing the expression of fibroblast growth factor 2 (FGF2) protein $(113,114)$. In addition, systemic delivery of miR-15a/16-1 resulted in a significant reduction of tumor growth and angiogenesis in colon cancer xenografts (115). Levels of miR-15a and miR-16-1 in CRC cells inversely correlate with their target cyclin B1 (CCNB1), a cell cycle regulatory protein associated with tumorigenic and metastatic features of CRC cells $(115,116)$.

Activation of the $\beta$-catenin/WNT signaling pathway is a key event in the development of CRC and has been linked to angiogenic processes in the tumor microenvironment (117). miR-29b targets transcription factor 7-like 2 (TCF7L2), SNAIL and B-cell CLL lymphoma 9-like protein (BCL9L) and it is associated with decreased translocation of $\beta$-catenin to nuclei in SW-480 colorectal adenocarcinoma cells $(118,119)$. Ectopic expression of miR-29b reduces the ability of SW-480 to induce tube formation in vitro, suggesting that miR-29b participates in angiogenic processes. Restoring miR-29b expression suppresses CRC tumor invasion and metastasis by reversing epithelial-mesenchymal transition (EMT) and by targeting MMP2 and T-cell lymphoma invasion and metastasis 1 (TIAM1) (118-120). miR-130b is another angiomiR that is overexpressed in advanced CRCs and promotes tumor growth through induction of EMT and angiogenesis (121). Tumors derived from cells that express high levels of miR-130b are highly vascularized. Notably, a direct functional target of miR-130b is peroxisome proliferator-activated receptor gamma (PPAR $\gamma$ ), a CRC-independent prognostic factor involved in cell differentiation and growth that is highly expressed in tumor endothelium $(121,122)$.

Both miR-27a and miR-27b have been described as angiogenesis modulators $(123,124)$. The role of miR-27a in $\mathrm{CRC}$ has been controversial. miR-27a has been detected as upregulated both in CRC cell lines and clinical tumors, and is considered oncogenic in several studies $(125,126)$. miR-27a was also reported as upregulated in adenoma and its expression increased during progression to adenocarcinoma (127). In addition, tumors derived from CRC cells with high expression of miR-27a correlated with low calreticulin expression and infiltration of $\mathrm{CD}^{+} \mathrm{T}$ cells, and were associated with distant metastasis and poor prognosis. Through a 2DE-DIGE proteomic analysis, miR-27a was identified as a post-transcriptional regulator of protein-encoding genes involved in MHC class I cell surface exposure which directly repressed calreticulin and inhibited cell proliferation and angiogenesis (127). By contrast, Bao et al (128) reported that miR-27a levels were significantly reduced in CRC tissues and cell lines. miR-27b also regulates tip cell fate, capillary sprouting and angiogenic mediators like semaphorin 6A, DLL4, SPRY2 and VEGFC $(123,124)$. In addition, the sphingosine-1-phosphate phosphatase 1 (SGPP1) and SMAD2 genes were reported as two targets of mR-27a (128). miR-27b expression was found downregulated in CRC tissues and in SW620 $\left(\mathrm{CD}^{3} 3^{+}\right)$cancer stem cells suggesting a role in stemness (129). Additionally, miR-27b restoration induced the 
production of largely necrotic xenografts with fewer capillary blood vessels and reduced tumor growth.

miR-192 inhibited metastasis by repressing key pro-metastatic genes, including B-cell lymphoma 2 (BCL2), zinc finger E-box binding homeobox 2 (ZEB2) and VEGFA in HCC (130). Further analysis of tumors from CRC patients revealed an inverse correlation between miR-192 expression and advanced tumor stages. miR-192 expression in models of CRC progression suppressed liver metastasis through VEGFA repression which resulted in reduced vascularization of primary tumors in vivo. In addition, VEGF expression and decreased AKT activation by miR-145 have been reported in mouse CRC xenograft tumors, and miR-145 expression inhibited tumor growth and angiogenesis (129). Furthermore, in CRC tissues, miR-145 levels inversely correlated with two of its known targets: N-RAS and insulin receptor substrate 1 (IRS1) (131). Finally, it was reported that miR-145 reduced HIF1 $\alpha$ and VEGF levels, potentially through repression of its upstream regulator p70S6K1 (132).

The insulin-like growth factor 1 receptor (IGFIR) is a transmembrane protein that activates downstream effectors involved in angiogenesis and tumorigenesis (133). miR-143 levels were significantly decreased in plasma samples and CRC tissues, and inversely correlated with IGF-IR levels in patients (134). miR-143 inhibited IGF-IR by binding to its 3'UTR, and also inactivated AKT, HIF-1 $\alpha$ and VEGF in SW1116 cells. Additionally, when these miR-143-expressing cells were subcutaneously injected into nude mice, they produced smaller tumors with reduced VEGF expression. Ectopic expression of miR-143 in SW1116 cells significantly suppressed angiogenesis in a chorioallantoic membrane system. Similarly, miR-23b, a repressor of prometastatic genes frizzled class receptor (7FZD7) and mitogen-activated protein kinase kinase kinase 1 (MAP3K1, was downregulated in CRC. Using a genome-wide functional screening, miR-23b was identified as an important suppressor of angiogenesis, tumor growth and invasion (135).

Activation of TGF $\beta /$ SMAD signaling induces EMT, a frequent event during cancer progression (136). Two angiomiRs, miR-885-3p and miR-1246, both target the SMAD pathway in CRC. miR-885-3p expression impairs the growth of HT-29 xenografts in nude mice and suppresses angiogenesis by disrupting the bone morphogenetic protein receptor type 1A (BMPR1A) and SMAD/ID1 signaling (137). miR-1246 was found in CRC-derived microvesicles which induce proliferation, migration and tube formation in HUVECs (138). The angiogenic identity of these microvesicles was attributed to activation of SMAD1/5/8 signaling in HUVECs by miR-1246 and TGF- $\beta$. This study suggests that CRC-derived microvesicles contribute to tumor angiogenesis.

AngiomiRs in ovarian cancer. Ovarian cancer (OC) is the second most common and the most fatal gynecologic cancer in women (139). Several research groups have identified distinct miRNAs involved in angiogenesis, tumorigenesis, metastasis and chemoresistance of OC (140-142). For instance, miR-199a, miR-125b and miR-145 have a key role in HIFl $\alpha$-mediated angiogenesis in OC. He et al (142) demonstrated that miR-199a and miR-125b were downregulated in epithelial ovarian carcinoma compared with normal tissues, and that they repressed angiogenesis by directly targeting pro-angiogenic factors HIF1 $\alpha$ and VEGF, through AKT/p70S6K1/HIF1 $\alpha$ signaling. Similarly, miR-145 was downregulated in OC tissues and cell lines and inhibited angiogenesis by targeting p70S6K. miR-145 inhibited the expression of both HIF1 $\alpha$ and VEGF (132). The expression of miR-497 was lower in OC tissues in comparison with normal tissues. Restoration of miR-497 resulted in decreased angiogenesis which was associated to suppression of VEGFA via PI3K/AKT and MAPK/ERK signaling pathways (143).

Another important mechanism of carcinogenesis mediated by hypoxia is the acquisition of resistance to chemotherapy. Several miRNAs, such as miR-484, miR-642 and miR-217, have been demonstrated to modulate VEGFB and VEGFR2 and predict tumor chemoresistance and increased angiogenesis in ovarian cancer (11). Furthermore, expression of miR-378 is decreased in OC cell lines and tumors compared with normal tissues. miR-378 inhibits the expression of genes associated with angiogenesis and apoptosis. Furthermore, the inhibition of ALCAM and EHD1 by miR-378 reduces the expression of the multidrug resistance gene (MDR) and is associated with progression-free survival (PFS) in a subgroup of patients who received anti-angiogenic therapy (144).

miRNAs may also modulate transcriptions factor function in ovarian cancer. Restoration of miR-27a represses VEGF expression, as well as COX2 and SP1 transcription factors (145). In addition, the miR-200 family, including miR-200a, b and c, inhibit EMT by downregulating ZEB1 and ZEB2 in diverse types of cancer, including ovarian tumors (146). Of note, miR-200 blocks angiogenesis by targeting IL8 and CXCL1 secreted by the endothelial cells, suggesting that miR-200 members can have therapeutic effects on angiogenesis and EMT-driven metastasis in ovarian cancer (147). Another study by Imam et al (148) demonstrated that genomic loci encoding miR-204 were frequently lost in multiple malignancies, including ovarian cancer. The restoration of miR-204 levels in ovarian cancer cells reduced overall tumor growth, cell proliferation and metastasis. In addition, the inhibition of brain-derived neurotrophic factor (BDNF) by miR-204 reduced angiogenesis and invasiveness, indicating that it acts as a tumor suppressor (148).

\section{Clinical applications of angiomiRs in cancer therapy}

A large number of anti-angiogenic agents are currently being tested for the treatment of diverse types of human malignancies. In the last decade, the Food and Drug Administration (FDA) has approved various anti-angiogenetic agents for the treatment of cancer, including monoclonal antibodies (e.g. bevacizumab) and tyrosine kinase inhibitors (e.g. sunitinib, sorafenib) (149). The anti-angiogenic activity of these drugs and antibodies are derived from their ability to block key angiogenic proteins, including VEGFA, VEGFR1/2/3, PDGFR1/2, p38, MAPK and FGFR1.

Currently, other anti-angiogenic compounds are being tested in clinical trials, although their approval might be jeopardized by unexpected toxicity, and resistance developing with molecular mechanisms poorly understood. The increasing research evidence supports an important role of miRNAs in angiogenesis, however this molecular knowledge needs to be properly 
translated into improvement of clinical management for cancer patients. At the pre-clinical level, several studies showed promising results in the potential clinical applications of miRNAs targeting angiogenesis. For instance, a previous report indicated that restoring miR-26 expression had dramatic effects in terms of tumor growth inhibition in a mouse model of hepatocelular carcinoma without remarkable toxicity (150). In addition, a recent study demonstrated that miR-204-expressing breast cancer cells suppressed angiogenesis in a nu/nu mice model (47). An in vivo analysis also demonstrated that the interplay between HMOX1 and miR-378 significantly modulates NSCLC progression and angiogenesis; miR-378-overexpressing tumors were larger, more vascularized and more metastatic, suggesting that miR-378 may serve as a novel therapeutic target (85). These and others findings certainly suggest that modulating miRNA expression could be a promising anti-angiogenic strategy in mouse models of cancer, however, further evidence is still needed to demonstrate successful application and low system toxicity in human patients.

At the clinical level, several trials using miRNAs as therapeutic agents are under development. For instance, the first-in-human phase I study called MesomiR-1 used TargomiRs as 2nd or 3rd line treatment for patients with recurrent malignant pleural mesothelioma and non-small cell lung cancer (ClinicalTrials.gov identifier, NCT02369198). TargomiRs are novel targeted minicells containing: A miR-16 mimic (the miR-16 family is a tumour suppressor with key roles in cell proliferation, migration and angiogenesis in a multiple cancer types); an EnGeneIC delivery vehicle [EDV; nonliving bacterial minicell carriers (nanoparticles)]; and a moiety to targets EDVs to EGFR-expressing cancer cells with an anti-EGFR bispecific antibody. For this study, 26 pleural mesothelioma patients were recruited at three major cancer centers in Sydney (Australia), received at least one Targomir dose (the maximum tolerated dose was $5 \times 10^{9}$ TargomiRs once weekly), the safety profile was acceptable, and 1 of 22 patients had an objective response that lasted 32 weeks. The results were recently published by van Zandwijk et al (151). The authors concluded an acceptable safety profile and early signs of activity of TargomiRs in patients, and highlighted the urgency for additional studies of TargomiRs in combination with chemotherapy or immune checkpoint inhibitors. Many of the side effects observed in this trial consisted of inflammatory reactions, which strongly supports the idea of an immunologic effect. In conclusion, although TargomiRs-based therapy was an example of a successful first-in-human use of a miRNA-based therapy for pleural mesothelioma patients, concerns about toxic and immune effects should be fully addressed.

Another study in humans focuses in the assessment of the potential therapeutic applications of tumor suppressor miR-34a, a non-coding RNA that downregulates the expression of multiple oncogenes across multiple signaling pathways, as well as genes involved in tumor immune evasion, angiogenesis and metastasis in endothelial cells and many malignancies $(68,152-154)$. This first-in-human, phase I study assessed the maximum tolerated dose (MTD), safety, pharmacokinetics, and clinical activity of MRX34, a liposomal miR-34a mimic, in patients with advanced solid tumors (ClinicicalTrials.gov identifier, NCT01829971). Adult patients with solid tumors refractory to standard treatment were enrolled in a standard $3+3$ dose escalation trial. MRX34 was administered intravenously twice weekly for three weeks in 4-week cycles. Forty-seven patients with various solid tumors, including hepatocellular carcinoma were enrolled. The authors concluded that MRX34 treatment with dexamethasone premedication was associated with acceptable safety and exhibited evidence of antitumor activity in a subset of patients with refractory advanced solid tumors (155).

\section{Conclusions}

Basic research into the roles of miRNAs in tumor angiogenesis has been increasing in the last decade. Although definitive clinical evidence about the potential therapeutic applications of angiomiRs in patients is still lacking, there is no doubt that these small RNAs deserve attention as attractive targets for development of novel anticancer drugs. An increased amount of anti-angiogenic compounds is currently in preclinical and clinical development for personalized cancer therapy. However, resistance to angiogenesis inhibitors is real, and highlights the need to identify alternative agents. Deciphering the molecular mechanisms of angiogenesis inhibition by miRNAs is imperative, as the successful translation of novel inhibitors to the clinic greatly depends on an in-depth understanding of the biology and function of miRNAs in tumor and endothelial cells. As chemotherapy is angiogenesis-dependent, the implementation of angiogenesis inhibitors to conventional therapies may have additional advantages. For instance, miRNAs targeting endothelial cells may have advantages over tumor-specific therapies, as they can overcome drug resistance the least in preclinical models.

The present review has summarized the current knowledge regarding the angiomiRs deregulation and functional mechanisms in diverse types of human cancers, which may provide a guide in their potential utilization as therapeutic targets in aggressive tumors. Several miRNAs have anti-angiogenic properties by targeting key angiogenic factors, including VEGF, HIF1 $\alpha$, PDGF, FGF, EGF, as well as MAPK, PI3K and TGF $\beta$ signaling, which offers a wide landscape of therapeutic opportunities. Finally, first-in-humans studies derived from controlled clinical trials showed an acceptable safety profile and antitumoral activity of miRNAs in patients, and highlighted the urgency for additional studies prior to potential routine clinical applications.

\section{Acknowledgements}

Not applicable.

\section{Funding}

The authors acknowledge the Consejo Nacional de Ciencia y Tecnología, Fondo de Investigación Científica Básica (grant no. 222335), and Fondo SSA/IMSS/ISSSTE (grant no. 233370) for financial support. YMSV received a CONACYT fellowship (grant no. 588430). The authors also acknowledge Grupo Mexicano De Investigacion En Cancer De Ovario Ac for financial support.

\section{Availability of data and materials}

Not applicable. 


\section{Authors' contributions}

YMSV, REZ and CLC reviewed the microRNA functions and produced the majority of this review. LAM and CLC discussed the roles of angiomiRs in lung and pancreatic cancer and the clinical applications of angiomiRs. DGR and HAV reviewed the role of angiomiRs in gynecological cancers. ERG discussed the role of angiomiRs in colorectal cancer.

\section{Ethics approval and consent to participate}

Not applicable.

\section{Patient consent for publication}

Not applicable.

\section{Competing interests}

The authors declare that they have no competing interests.

\section{References}

1. Weis SM and Cheresh DA: Tumor angiogenesis: Molecular pathways and therapeutic targets. Nat Med 17: 1359-1370, 2011.

2. Maniotis AJ, Folberg R, Hess A, Seftor EA, Gardner LM, Pe'er J, Trent JM, Meltzer PS and Hendrix MJ: Vascular channel formation by human melanoma cells in vivo and in vitro: Vasculogenic mimicry. Am J Pathol 155: 739-752, 1999.

3. Semenza GL: Targeting HIF-1 for cancer therapy. Nat Rey Cancer 3: 721-732, 2003.

4. Cai X, Hagedorn $\mathrm{CH}$ and Cullen BR: Human microRNAs are processed from capped, polyadenylated transcripts that can also function as mRNAs. RNA 10: 1957-1966, 2004.

5. Han J, Lee Y, Yeom KH, Kim YK, Jin H and Kim VN: The Drosha-DGCR8 complex in primary microRNA processing. Genes Dev 18: 3016-3027, 2004.

6. Ruby JG, Jan CH and Bartel DP: Intronic microRNA precursors that bypass Drosha processing. Nature 448: 83-86, 2007.

7. Chendrimada TP, Gregory RI, Kumaraswamy E, Norman J, Cooch N, Nishikura K and Shiekhattar R: TRBP recruits the Dicer complex to Ago2 for microRNA processing and gene silencing. Nature 436: 740-744, 2005.

8. Vasudevan S, Tong Y and Steitz JA: Switching from repression to activation: microRNAs can up-regulate translation. Science 318: 1931-1934, 2007.

9. Sen GL and Blau HM: Argonaute 2/RISC resides in sites of mammalian mRNA decay known as cytoplasmic bodies. Nat. Cell Biol 7: 633-636, 2005.

10. Bertoli G, Cava C and Castiglioni I: MicroRNAs: New biomarkers for diagnosis, prognosis, therapy prediction and therapeutic tools for breast cancer. Theranostics 5: 1122-1143, 2015.

11. Vecchione A, Belletti B, Lovat F, Volinia S, Chiappetta G Giglio S, Sonego M, Cirombella R, Onesti EC, Pellegrini P, et al: A microRNA signature defines chemoresistance in ovarian cancer through modulation of angiogenesis. Proc Natl Acad Sci USA 110: 9845-9850, 2013.

12. Borges NM, do Vale Elias M, Fook-Alves VL, Andrade TA, de Conti ML, Macedo MP, Begnami MD, Campos AH, Etto LY, Bortoluzzo AB, et al: Angiomirs expression profiling in diffuse large B-Cell lymphoma. Oncotarget 7: 4806-4816, 2016.

13. Suárez Y and Sessa WC: MicroRNAs as novel regulators of angiogenesis. Circ Res 104: 442-454, 2009.

14. Suzuki HI, Katsura A, Matsuyama H and Miyazono K: MicroRNA regulons in tumor microenvironment. Oncogene 34: 3085-3094, 2015.

15. Bernstein E, Kim SY, Carmell MA, Murchison EP, Alcorn H, Li MZ, Mills AA, Elledge SJ, Anderson KV and Hannon G: Dicer is essential for mouse development. Nat Genet 35: 215-217, 2003.

16. Yang WJ, Yang DD, Na S, Sandusky GE, Zhang Q and Zhao G Dicer is required for embryonic angiogenesis during mouse development. J Biol Chem 280: 9330-9335, 2005.
17. Suárez Y, Fernández-Hernando C, Yu J, Gerber SA, Harrison KD, Pober JS, Iruela-Arispe ML, Merkenschlager M and Sessa WC: Dicer-dependent endothelial microRNAs are necessary for postnatal angiogenesis. Proc Natl Acad Sci USA 105: 14082-14087, 2008.

18. Kuehbacher A, Urbich C, Zeiher AM and Dimmeler S: Role of Dicer and Drosha for endothelial microRNA expression and angiogenesis. Circ Res 101: 59-68, 2007.

19. Suárez Y, Fernández-Hernando C, Pober JS and Sessa WC: Dicer dependent microRNAs regulate gene expression and functions in human endothelial cells. Circ Res 100: 1164-1173, 2007.

20. Poliseno L, Tuccoli A, Mariani L, Evangelista M, Citti L, Woods K, Mercatanti A, Hammond S and Rainaldi G: MicroRNAs modulate the angiogenic properties of HUVECs. Blood 108: 3068-3071, 2006.

21. Heusschen R, van Gink M, Griffioen AW and Thijssen VL: MicroRNAs in the tumor endothelium: Novel controls on the angioregulatory switchboard. Biochim Biophys Acta 1805: 87-96, 2010.

22. McCall M, Kent O, Yu J, Fox-Talbot K, Zaiman A and Halushka M: MicroRNA profiling of diverse endothelial cell types. BMC Med Genomics 4: 78, 2011.

23. Shen G, Li X, Jia Y, Piazza G and Xi Y: Hypoxia-regulated microRNAs in human cancer. Acta Pharmacol Sin 34: 336-341, 2013.

24. van Beijnum J, Giovannetti E, Poel D, Nowak-Sliwinska P and Griffioe A: miRNAs: micro-managers of anticancer combination therapies. Angiogenesis 20: 269-285, 2017.

25. Siegel R, Miller K and Jemal A: Cancer statistics, 2015. CA Cancer J Clin 65: 5-29, 2015.

26. Parker L, Schmidt M, Jin S, Gray A, Beis D, Pham T, Frantz G, Palmieri S, Hillan K, Stainier D, et al: The endothelial-cell-derived secreted factor Egfl7 regulates vascular tube formation. Nature 428: 754-758, 2004

27. Meister J and Schmidt M: miR-126 and miR-126*: New players in cancer. ScientificWorld J 10: 2090-2100, 2010.

28. Zhu N, Zhang D, Xie H, Zhou Z, Chen H, Hu T, Bai Y, Shen Y, Yuan W, Jing Q and Qin Y: Endothelial-specific intron-derived miR-126 is down-regulated in human breast cancer and targets both VEGFA and PIK3R2. Mol Cell Biochem 351: 57-164, 2011.

29. Lu YY, Sweredoski MJ, Huss D, Lansford R, Hess S and Tirrell DA: Prometastatic GPCR CD97 is a direct target of tumor suppressor microRNA-126. ACS Chem Biol 9: 334-338, 2014.

30. Zhang Y, Yang P, Sun T, Li D, Xu X, Rui Y, Li C, Chong M, Ibrahim T, Mercatali L, et al: miR-126 and miR-126* repress recruitment of mesenchymal stem cells and inflammatory monocytes to inhibit breast cancer metastasis. Nat Cell Biol 15: 284-294, 2013.

31. Png KJ, Halberg N, Yoshida M and Tavazoie SF: A microRNA regulon that mediates endothelial recruitment and metastasis by cancer cells. Nature 481: 190-194, 2011.

32. Wu Z, Cai X, Huang C, Xu J and Liu A: miR-497 suppresses angiogenesis in breast carcinoma by targeting HIF-1 $\alpha$. Oncol Rep 35: 1696-1702, 2016.

33. Tu Y, Liu L, Zhao D, Liu Y, Ma X, Fan Y, Wan L, Huang T, Cheng $\mathrm{Z}$ and Shen B: Overexpression of miRNA-497 inhibits tumor angiogenesis by targeting VEGFR2. Sci Rep 5: 13827, 2015.

34. Fox S, Generali D and Harris A: Breast tumour angiogenesis. Breast Cancer Res 9: 216, 2017.

35. Chang S, Wang R, Akagi K, Kim K, Martin B, Cavallone L; Kathleen Cuningham Foundation Consortium for Research into Familial Breast Cancer (kConFab), Haines DC, Basik M, Mai P, et al: Tumor suppressor BRCA1 epigenetically controls oncogenic microRNA-155. Nat Med 17: 1275-1282, 2011.

36. Danza K, De Summa S, Pinto R, Pilato B, Palumbo O, Merla G, Simone G and Tommasi S: MiR-578 and miR-573 as potential players in BRCA-related breast cancer angiogenesis. Oncotarget 6: 471-483, 2015.

37. Kong W, He L, Coppola M, Guo J, Esposito NN, Coppola D and Cheng JQ: MicroRNA-155 regulates cell survival, growth, and chemosensitivity by targeting FOXO3a in breast cancer. J Biol Chem 285: 17869-17879, 2016.

38. Kong W, He L, Richards EJ, Challa S, Xu CX, Permuth-Wey J, Lancaster JM, Coppola D, Sellers TA, Djeu JY and Cheng JQ: Upregulation of miRNA-155 promotes tumour angiogenesis by targeting VHL and is associated with poor prognosis and triple-negative breast cancer. Oncogene 33: 679-689, 2014. 
39. Foekens J, Sieuwerts A, Smid M, Look M, de Weerd V, Boersma A, Klijn J, Wiemer E and Martens J: Four miRNAs associated with aggressiveness of lymph node-negative, estrogen receptor-positive human breast cancer. Proc Natl Acad Sci USA 105: 13021-13026, 2008.

40. Yan LX, Huang XF, Shao Q, Huang MY, Deng L, Wu QL, Zeng YX and Shao JY: MicroRNA miR-21 overexpression in human breast cancer is associated with advanced clinical stage, lymph node metastasis and patient poor prognosis. RNA 14: 2348-2360, 2008.

41. Zhao D, Tu Y, Wan L, Bu L, Huang T, Sun X, Wang K and Shen B: In vivo monitoring of angiogenesis inhibition via down-regulation of mir-21 in a VEGFR2-luc murine breast cancer model using bioluminescent imaging. PLoS One 8: e71472, 2013.

42. Mathsyaraja H, Thies K, Taffany D, Deighan C, Liu T, Yu L, Fernandez S, Shapiro C, Otero J, Timmers C, et al: CSF1-ETS2-induced microRNA in myeloid cells promote metastatic tumor growth. Oncogene 34: 3651-3661, 2015.

43. He T, Qi F, Jia L, Wang S, Song N, Guo L, Fu Y and Luo Y: MicroRNA-542-3p inhibits tumour angiogenesis by targeting angiopoietin-2. J Pathol 232: 499-508, 2014.

44. He T, Qi F, Jia L, Wang S, Wang C, Song N, Fu Y, Li L and Luo Y: Tumor cell-secreted angiogenin induces angiogenic activity of endothelial cells by suppressing miR-542-3p. Cancer Lett 368: 115-125, 2015.

45. Leidner RS, Li L and Thompson CL: Dampening enthusiasm for circulating microRNA in breast cancer. PLoS One 8: e57841, 2013.

46. Li JT, Wang LF, Zhao YL, Yang T, Li W, Zhao J, Yu F, Wang L, Meng YL, Liu NN, et al: Nuclear factor of activated T cells 5 maintained by Hotair suppression of miR-568 upregulates S100 calcium binding protein A4 to promote breast cancer metastasis. Breast Cancer Res 16: 454, 2014.

47. Flores-Pérez A, Marchat L, Rodríguez-Cuevas S, Bautista-Piña V, Hidalgo-Miranda A, Ocampo E, Martínez M, Palma-Flores C, Fonseca-Sánchez M, Astudillo-de la Vega $\mathrm{H}$, et al: Dual targeting of ANGPT1 and TGFBR2 genes by miR-204 controls angiogenesis in breast cancer. Sci Rep 6: 34504, 2016.

48. Kirschmann DA, Seftor EA, Hardy KM, Seftor RE and Hendrix MJ: Molecular pathways: Vasculogenic mimicry in tumor cells: Diagnostic and therapeutic implications. Clin Cancer Res 18: 2726-3272, 2012.

49. Salinas-Vera YM, Marchat LA, García-Vázquez R, González de la Rosa CH, Castañeda-Saucedo E, Tito NN, Flores CP, Pérez-Plasencia C, Cruz-Colin JL, Carlos-Reyes A, et al: Cooperative multi-targeting of signaling networks by angiomiR-204 inhibits vasculogenic mimicry in breast cancer cells. Cancer Lett 432: 17-27, 2018.

50. American Cancer Society. Cancer facts and figures 2015. Atlanta: American Cancer Society 1-52, 2015.

51. Abramson MA, Jazag A, van der Zee JA and Whang EE: The molecular biology of pancreatic cancer. Gastrointest Cancer Res 1 (4 Suppl 2): S7-S12, 2007.

52. Carr RM and Fernandez-Zapico ME: Pancreatic cancer microenvironment, to target or not to target? EMBO Mol Med 8: 80-82, 2016

53. Khan S, Ansarullah, Kumar D, Jaggi $M$ and Chauhan SC: Targeting microRNAs in pancreatic cancer: Microplayers in the big game. Cancer Res 73: 6541-6547, 2013.

54. Mace TA, Collins AL, Wojcik SE, Croce CM, Lesinski GB and Bloomston M: Hypoxia induces the overexpression of microRNA-21 in pancreatic cancer cells. J Surg Res 184: 855-860, 2013.

55. Volinia S, Calin G, Liu C, Ambs S, Cimmino A, Petrocca F, Visone R, Iorio M, Roldo C, Ferracin M, et al: A microRNA expression signature of human solid tumors defines cancer gene targets. Proc Natl Acad Sci USA 103: 2257-2261, 2006.

56. Lee EJ, Gusev Y, Jiang J, Nuovo GJ, Lerner MR, Frankel WL, Morgan DL, Postier RG, Brackett DJ and Schmittgen TD: Expression profiling identifies microRNA signature in pancreatic cancer. Int J Cancer 120: 1046-1054, 2007.

57. Moriyama T, Ohuchida K, Mizumoto K, Yu J, Sato N, Nabae T, Takahata S, Toma H, Nagai E and Tanaka M: MicroRNA-21 modulates biological functions of pancreatic cancer cells including their proliferation, invasion, and chemoresistance. Mol Cancer Ther 8: 1067-1074, 2009.

58. Bao B, Ali S, Kong D, SarkarS, Wang Z, Banerjee S, Aboukameel A, Padhye S, Philip P and Sarkar F: Anti-tumor activity of a novel compound-CDF is mediated by regulating miR-21, miR-200, and PTEN in pancreatic cancer. PLoS One 6: e17850, 2011.

59. Kadera BE, Li L, Toste PA, Wu N, Adams C, Dawson DW and Donahue TR: MicroRNA-21 in pancreatic ductal adenocarcinoma tumor-associated fibroblasts promotes metastasis. PLoS One 8: e71978, 2013.
60. Hoffmann A, Mori R, Vallbohmer D, Brabender J, Klein E, Drebber U, Baldus S, Cooc J, Azuma M, Metzger R, et al: High expression of HIFla is a predictor of clinical outcome in patients with pancreatic ductal adenocarcinomas and correlated to PDGFA, VEGF, and bFGF. Neoplasia 10: 674-679, 2008.

61. Wang X, Ren H, Zhao T, Ma W, Dong J, Zhang S, Xin W, Yang S, Jia L and Hao J: Single nucleotide polymorphism in the microRNA-199a binding site of HIF1A gene is associated with pancreatic ductal adenocarcinoma risk and worse clinical outcomes. Oncotarget 7: 13717-1329, 2016.

62. Chan YC, Roy S, Huang Y, Khanna S and Sen C: The microRNA miR-199a-5p down-regulation switches on wound angiogenesis by derepressing the v-ets erythroblastosis virus E26 oncogene homolog 1-matrix metalloproteinase-1 pathway. J Biol Chem 287: 41032-41043, 2012.

63. Morton J, Timpson P, Karim S, Ridgway R, Athineos D, Doyle B, Jamieson N, Oien K, Lowy A, Brunton V, et al: Mutant p53 drives metastasis and overcomes growth arrest/senescence in pancreatic cancer. Proc Natl Acad Sci USA 107: 246-251, 2010.

64. Frampton A, Krell J, Jamieson N, Gall T, Giovannetti E, Funel N, Mato Prado M, Krell D, Habib N, Castellano L, et al: microRNAs with prognostic significance in pancreatic ductal adenocarcinoma: A meta-analysis. Eur J Cancer 51: 1389-1404, 2015.

65. Alemar B, Izetti P, Gregório C, Macedo GS, Castro MA, Osvaldt AB, Matte U and Ashton-Prolla P: miRNA-21 and miRNA-34a are potential minimally invasive biomarkers for the diagnosis of pancreatic ductal adenocarcinoma. Pancreas 45: 84-92, 2016.

66. Chang T, Wentzel E, Kent O, Ramachandran K, Mullendore M, Lee KH,Feldmann G, Yamakuchi M,Ferlito M, Lowenstein C, et al: Transactivation of miR-34a by p53 broadly influences gene expression and promotes apoptosis. Mol Cell 26: 745-752, 2007.

67. Vogt M, Munding J, Grüner M, Liffers ST, Verdoodt B Hauk J, Steinstraesser L, Tannapfel A and Hermeking H: Frequent concomitant inactivation of miR-34a and miR-34b/c by $\mathrm{CpG}$ methylation in colorectal, pancreatic, mammary, ovarian, urothelial, and renal cell carcinomas and soft tissue sarcomas. Virchows Arch 458: 313-322, 2011.

68. Zhao T, Li J and Chen AF: MicroRNA-34a induces endothelial progenitor cell senescence and impedes its angiogenesis via suppressing silent information regulator 1. Am J Physiol Endocrinol Metab 299: E110-E116, 2010.

69. Dela Cruz CS, Tanoue LT and Matthay RA: Lung cancer: Epidemiology, etiology, and prevention. Clin Chest Med 32: 605-644, 2011.

70. Bremnes RM, Camps C and Sirera R: Angiogenesis in non-small cell lung cancer: The prognostic impact of neoangiogenesis and the cytokines VEGF and bFGF in tumours and blood. Lung Cancer 51: 143-158, 2006.

71. Korpanty G, Smyth E and Carney D: Update on anti-angiogenic therapy in non-small cell lung cancer: Are we making progress? J Thorac Dis 3: 19-29, 2011

72. Al Farsi A and Ellis P: Anti-angiogenic therapy in advanced non-small cell lung carcinoma (NSCLC): Is there a role in subsequent lines of therapy? J Thorac Dis 7: 214-216, 2015.

73. Chen S, Xue Y, Wu X, Le C, Bhutkar A, Bell L, Zhang F, Langer R and Sharp PA: Global microRNA depletion suppresses tumor angiogenesis. Genes Dev 28: 1054-1067, 2014.

74. Donnem T, Fenton CG, Lonvik K, Berg T, Eklo K, Andersen S, Stenvold H, Al-Shibli K, Al-Saad S, Bremnes RM and Busund LT: MicroRNA signatures in tumor tissue related to angiogenesis in non-small cell lung cancer. PLoS One 7: e29671, 2012.

75. Liu B, Peng XC, Zheng XL, Wang J and Qin YW: MiR-126 restoration down-regulate VEGF and inhibit the growth of lung cancer cell lines in vitro and in vivo. Lung Cancer 66: 169-175, 2009.

76. Donnem T, Lonvik K, Eklo K, Berg T, Sorbye SW, Al-Shibli K, Al-Saad S, Andersen S, Stenvold H, Bremnes RM and Busund LT: Independent and tissue-specific prognostic impact of miR-126 in nonsmall cell lung cancer: Coexpression with vascular endothelial growth factor-A predicts poor survival. Cancer 117: 3193-3200, 2011

77. Jusufović E, Rijavec M, Keser D, Korošec P, Sodja E, Iljazović E Radojević Z and Košnik M: le7 and miR-126 are down-regulated in tumor tissue and correlate with microvessel density and survival outcomes in non-small-cell lung cancer. PLoS One 7: e45577, 2012.

78. Chen Z, Lai TC, Jan YH, Lin FM, Wang WC, Xiao H, Wang YT, Sun W, Cui X, Li YS, et al: Hypoxia-responsive miRNAs target argonaute 1 to promote angiogenesis. J Clin Invest 123: 1057-1067, 2013. 
79. Takamizawa J, Konishi H, Yanagisawa K, Tomida S, Osada H, Endoh H, Harano T, Yatabe Y, Nagino M, Nimura Y, et al: Reduced expression of the let-7 microRNAs in human lung cancers in association with shortened postoperative survival. Cancer Res 64: 3753-3756, 2004.

80. Yanaihara N, Caplen N, Bowman E, Seike M, Kumamoto K, Yi M, Stephens M, Okamoto A, Yokota J, Tanaka T, et al: Unique microRNA molecular profiles in lung cancer diagnosis and prognosis. Cancer Cell 9: 189-198, 2006.

81. Hu J, Cheng Y, Li Y, Jin Z, Pan Y, Liu G, Fu S, Zhang Y, Feng K and Feng Y: microRNA-128 plays a critical role in human non-small cell lung cancer tumourigenesis, angiogenesis and lymphangiogenesis by directly targeting vascular endothelial growth factor-C. Eur J Cancer 50: 2336-2350, 2014.

82. Tejero R, Navarro A, Campayo M, Viñolas N, Marrades M, Cordeiro A, Ruíz-Martínez M, Santasusagna S, Molins L, Ramirez J and Monzó M: miR-141 and miR-200c as markers of overall survival in early stage non-small cell lung cancer adenocarcinoma. PLoS One 9: e101899, 2014

83. Owen S and Souhami L: The management of brain metastases in non-small cell lung cancer. Front Oncol 4: 248, 2014.

84. Chen LT, Xu SD, Xu H, Zhang JF, Ning JF and Wang SF MicroRNA-378 is associated with non-small cell lung cancer brain metastasis by promoting cell migration, invasion and tumor angiogenesis. Med Oncol 9: 1673-1680, 2012.

85. Skrzypek K, Tertil M, Golda S, Ciesl M, Weglarczyk K, Collet G, Guichard A, Kozakowska M, Boczkowski J, Was H, et al Interplay between heme oxygenase-1 and miR-378 affects non-small cell lung carcinoma growth, vascularization, and metastasis. Antioxid Redox Signal 9: 644-660, 2013.

86. Mao G, Liu Y, Fang X, Liu Y, Fang L, Lin L, Liu X and Wang N: Tumor-derived microRNA-494 promotes angiogenesis in non-small cell lung cancer. Angiogenesis 18: 373-382, 2015.

87. Zhao WY, Wang Y, An ZJ, Shi CG, Zhu GA, Wang B, Lu MY, Pan CK and Chen P: Downregulation of miR-497 promotes tumor growth and angiogenesis by targeting HDGF in non-small cell lung cancer. Biochem Biophys Res Commun 435: 466-447, 2013.

88. Kumarswamy R, Volkmann I, Beermann J, Napp LC, Jabs O, Bhayadia R, Melk A, Ucar A, Chowdhury K, Lorenzen JM, et al Vascular importance of the miR-212/132 cluster. Eur Heart J 35: 3224-3231, 2014

89. You J, Li Y, Fang N, Liu B, Zu L, Chang R, Li X and Zhou Q: MiR-132 suppresses the migration and invasion of lung cancer cells via targeting the EMT regulator ZEB2. PLoS One 9. e91827, 2014.

90. Incoronato M, Urso L, Portela A, Laukkanen MO, Soini Y, Quintavalle C, Keller S, Esteller M and Condorelli G: Epigenetic regulation of miR-212 expression in lung cancer. PLoS One 6 : e27722, 2011

91. Luo J, Meng C, Tang Y, Zhang S, Wan M, Bi Y and Zhou X: miR-132/212 cluster inhibits the growth of lung cancer xenografts in nude mice. Int J Clin Exp Med 7: 4115-4122, 2014

92. Cui H, Seubert B, Stahl E, Dietz H, Reuning U, Moreno-Leon L, Ilie M, Hofman P, Nagase H, Mari B and Krüger A: Tissue inhibitor of metalloproteinases-1 induces a pro-tumourigenic increase of miR-210 in lung adenocarcinoma cells and their exosomes. Oncogene 34: 3640-3650, 2015.

93. Pesta M, Kulda V, Kucera R, Pesek M, Vrzalova J, Liska V, Pecen L, Treska V, Safranek J, Prazakova M, et al: Prognostic significance of TIMP-1 in non-small cell lung cancer. Anticancer Res 31: 4031-4038, 2011

94. American Cancer Society: Cancer facts and figures 2016 Atlanta, Ga: American Cancer Society, 2016.

95. Hur K, Toiyama Y, Schetter AJ, Okugawa Y, Harris CC, Boland CR and Goel A: Identification of a metastasis-specific MicroRNA signature in human colorectal cancer. J Natl Cancer Inst 107: dju492, 2015 .

96. Yamaguchi T, Iijima T, Wakaume R, Takahashi K, Matsumoto $H$, Nakano D, Nakayama, Y Mori T, Horiguchi S and Miyaki M: Underexpression of miR-126 and miR-20b in hereditary and nonhereditary colorectal tumors. Oncology 87: 58-66, 2014.

97. Zhang Y, Wang X, Xu B, Wang B, Wang Z, Liang Y, Zhou J, $\mathrm{Hu} \mathrm{J}$ and Jiang B: Epigenetic silencing of miR-126 contributes to tumor invasion and angiogenesis in colorectal cancer. Oncol Rep 30: 1976-1984, 2013.

98. Hansen TF, Andersen CL, Nielsen BS, Spindler KL, Sørensen FB, Lindebjerg J, Brandslund I and Jakobsen A: Elevated microRNA-126 is associated with high vascular endothelial growth factor receptor 2 expression levels and high microvessel density in colorectal cancer. Oncol Lett 2: 1101-1106, 2011.
99. Hansen TF, Christensen Rd, Andersen RF, Sørensen FB, Johnsson A and Jakobsen A: MicroRNA-126 and epidermal growth factor-like domain 7-an angiogenic couple of importance in metastatic colorectal cancer. Results from the Nordic ACT trial. Br J Cancer 109: 1243-1251, 2013.

100. Yu W, Wang Z, Shen, LI and Wei Q: Circulating microRNA-21 as a potential diagnostic marker for colorectal cancer: A meta-analysis. Mol Clin Oncol 4: 237-244, 2016

101. Slaby O, Svoboda M, Fabian P, Smerdova T, Knoflickova D, Bednarikova M, Nenutil R and Vyzula R: Altered expression of miR-21, miR-31, miR-143 and miR-145 is related to clinicopathologic features of colorectal cancer. Oncology 72: 397-402, 2007.

102. Nielsen S, Jørgensen S, Fog JU, Søkilde R, Christensen IJ, Hansen U, Brünner N, Baker A, Møller S and Nielsen HJ: High levels of microRNA-21 in the stroma of colorectal cancers predict short disease-free survival in stage II colon cancer patients. Clin Exp Metastasis 28: 27-38, 2011.

103. Nagao Y, Hisaoka M, Matsuyama A, Kanemitsu S, Hamada T, Fukuyama T, Nakano R, Uchiyama A, Kawamoto $M$ Yamaguchi $\mathrm{K}$ and Hashimoto $\mathrm{H}$ : Association of microRNA-21 expression with its targets, PDCD4 and TIMP3, in pancreatic ductal adenocarcinoma. Mod Pathol 25: 112-121, 2012.

104. Song MS and Rossi JJ: The anti-miR21 antagomir, a therapeutic tool for colorectal cancer, has a potential synergistic effect by perturbing an angiogenesis-associated miR30. Front Genet 4: 301, 2014.

105. Bridge G, Monteiro R, Henderson S, Emuss V, Lagos D, Georgopoulou D, Patient R and Boshoff C: The microRNA-30 family targets DLL4 to modulate endothelial cell behavior during angiogenesis. Blood 120: 5063-5072, 2012.

106. Hellström M, Phng LK, Hofmann JJ, Wallgard E, Coultas L, Lindblom P, Alva J, Nilsson AK, Karlsson L, Gaiano N, et al: Dll4 signalling through Notch1 regulates formation of tip cells during angiogenesis. Nature 445: 776-780, 2007.

107. Miyanaga K, Kato Y, Nakamura T, Matsumura M, Amaya H, Horiuchi T, Chiba Y and Tanaka K: Expression and role of thrombospondin-1 in colorectal cancer. Anticancer Res 22: 3941-3948, 2002.

108. Diosdado B, van de Wiel A, Terhaar Sive Droste S, Mongera S, Postma C, Meijerink WJ, Carvalho B and Meijer GA: MiR-17-92 cluster is associated with $13 \mathrm{q}$ gain and c-myc expression during colorectal adenoma to adenocarcinoma progression. $\mathrm{Br}$ J Cancer 101: 707-714, 2009.

109. Dews M, Homayouni A, Yu D, Murphy D, Sevignani C Wentzel E, Furth E, Lee M, Enders H, Mendell T and Thomas-Tikhonenko A: Augmentation of tumor angiogenesis by a Myc-activated microRNA cluster. Nat Genet 38: 1060-1065, 2006.

110. Amodeo V, Bazan V, Fanale D, Insalaco L, Caruso S Cicero G, Bronte G, Rolfo C, Santini D and Russo A: Effects of anti-miR-182 on TSP-1 expression in human colon cancer cells: There is a sense in antisense? Expert Opin Ther Targets 17: 1249-1261, 2013.

111. Liang Y, Ridzon D, Wong L and Chen C: Characterization of microRNA expression profiles in normal human tissues. BMC Genomics 8: 166, 2007.

112. Sundaram P, Hultine S, Smith LM, Dews M, Fox JL, Biyashev D, Schelter JM, Huang Q, Cleary MA, Volpert OV and Thomas-Tikhonenko A: p53-responsive miR-194 inhibits thrombospondin-1 and promotes angiogenesis in colon cancers. Cancer Res 71: 7490-7501, 2011.

113. Braun CJ, Zhang X, Savelyeva I, Wolff S, Moll UM, Schepeler T, Ørntoft TF, Andersen CL and Dobbelstein M: p53-responsive micrornas 192 and 215 are capable of inducing cell cycle arrest. Cancer Res 68: 10094-10104, 2008.

114. Xue G, Yan HL, Zhang Y, Hao LQ, Zhu XT, Mei Q and Sun SH: c-Myc-mediated repression of miR-15-16 in hypoxia is induced by increased HIF-2 $\alpha$ and promotes tumor angiogenesis and metastasis by upregulating FGF2. Oncogene 34: 1393-1406, 2015.

115. Dai L, Wang W, Zhang S, Jiang Q, Wang R, Dai L, Cheng, L, Yang Y, Wei YQ and Deng HX: Vector-based miR-15a/16-1 plasmid inhibits colon cancer growth in vivo. Cell Biol Int 36: 765-770, 2012

116. Fang Y, Liang X, Jiang W, Li J, Xu J and Cai X: Cyclin b1 suppresses colorectal cancer invasion and metastasis by regulating e-cadherin. PLoS One 10: e0126875, 2015.

117. Planutis K, Planutiene $\mathrm{M}$ and Holcombe F: A novel signaling pathway regulates colon cancer angiogenesis through Norrin. Sci Rep 4: 5630, 2014. 
118. Wang B, Li W, Liu H, Yang L, Liao Q, Cui S, Wang H and Zhao L: miR-29b suppresses tumor growth and metastasis in colorectal cancer via downregulating Tiam1 expression and inhibiting epithelial-mesenchymal transition. Cell Death Dis 17: e1335, 2014.

119. Subramanian M, Rao SR, Thacker P, Chatterjee S and Karunagaran D: MiR-29b downregulates canonical Wnt signaling by suppressing coactivators of $\beta$-catenin in human colorectal cancer cells. J Cell Biochem 115: 1974-1984, 2014.

120. Ding Q, Chang CJ, Xie X, Xia W, Yang Y, Wang SC, Wang Y, $\mathrm{Xia} J$, Chen L, Cai C, et al: APOBEC3G promotes liver metastasis in an orthotopic mouse model of colorectal cancer and predicts human hepatic metastasis. J Clin Invest 121: 4526-4536, 2011.

121. Colangelo T, Fucci A, Votino C, Sabatino L, Pancione M, Laudanna C, Binaschi M, Bigioni M, Maggi A, Parente D, et al: MicroRNA-130b promotes tumor development and is associated with poor prognosis in colorectal cancer. Neoplasia 15: 1086-1099, 2013.

122. Panigrahy D, Singer S, Shen LQ, Butterfield CE, Freedman DA, Chen EJ, Moses MA, Kilroy S, Duensing S, Fletcher C, et al: PPARgamma ligands inhibit primary tumor growth and metastasis by inhibiting angiogenesis. J Clin Invest 110: 923-932, 2002.

123. Urbich C, Kaluza D, Frömel T, Knau A, Bennewitz K, Boon RA Bonauer A, Doebele C, Boeckel JN, Hergenreider E, et al: MicroRNA-27a/b controls endothelial cell repulsion and angiogenesis by targeting semaphorin 6A. Blood 119: 1607-1616, 2012.

124. Veliceasa D, Biyashev D, Qin G, Misener S, Mackie AR, Kishore R and Volpert OV: Therapeutic manipulation of angiogenesis with miR-27b. Vasc Cell 24: 6, 2015.

125. Chintharlapalli S, Papineni S, Abdelrahim M, Abudayyeh A, Jutooru I, Chadalapaka G, Wu F, Mertens-Talcott S, Vanderlaag K, Cho D, et al: Oncogenic microRNA-27a is a target for anticancer agent methyl 2-cyano-3,11-dioxo-18betaolean-1,12-dien-30-oate in colon cancer cells. Int J Cancer 125: 1965-1974, 2009.

126. Pathi S, Jutooru I, Chadalapaka G, Sreevalsan S, Anand S, Thatcher GR and Safe S: GT-094, a NO-NSAID, inhibits colon cancer cell growth by activation of a reactive oxygen species-microRNA-27a: ZBTB10-specificity protein pathway. Mol Cancer Res 9: 195-202, 2011.

127. Colangelo T, Polcaro G, Ziccardi P, Pucci B, Muccillo L, Galgani M,Fucci A, Milone MR, Budillon A, Santopaolo M, et al: Proteomic screening identifies calreticulin as a miR-27a direct target repressing MHC class I cell surface exposure in colorectal cancer. Cell Death Dis 25: e2120, 2016.

128. Bao Y, Chen Z, Guo Y, Feng Y, Li Z, Han W, Wang J, Zhao W, Jiao Y,Li K, et al: Tumor suppressor microRNA-27a in colorectal carcinogenesis and progression by targeting SGPP1 and Smad2. PLoS One 9: e105991, 2014.

129. Ye J, Wu X, Wu D, Wu P, Ni C, Zhang Z, Chen Z, Qiu F, Xu J and Huang J: miRNA-27b targets vascular endothelial growth factor $\mathrm{C}$ to inhibit tumor progression and angiogenesis in colorectal cancer. PLoS One 8: e60687, 2013.

130. Geng L, Chaudhuri A, Talmon G, Wisecarver JL, Are C, Brattain M and Wang J: MicroRNA-192 suppresses liver metastasis of colon cancer. Oncogene 33: 5332-5340, 2014.

131. Yin Y, Yan ZP, Lu NN, Xu Q, He J, Qian X, Yu J, Guan X, Jiang BH and Liu LZ: Downregulation of miR-145 associated with cancer progression and VEGF transcriptional activation by targeting N-RAS and IRS1. Biochim Biophys Acta 1829: 239-247, 2013.

132. Xu Q, Liu LZ, Qian X, Chen Q, Jiang Y, Li D, Lai L and Jiang BH: MiR-145 directly targets p70S6K1 in cancer cells to inhibit tumor growth and angiogenesis. Nucleic Acids Res 40: 761-774, 2012

133. Bustin SA, Dorudi S, Phillips SM, Feakins RM, Jenkins PJ: Local expression of insulin-like growth factor-I affects angiogenesis in colorectal cancer. Tumour Biol 23: 130-138, 2002

134. Qian X, Yu J, Yin Y, He J, Wang L, Li Q, Zhang LQ, Li CY, Shi ZM, Xu Q, et al: MicroRNA-143 inhibits tumor growth and angiogenesis and sensitizes chemosensitivity to oxaliplatin in colorectal cancers. Cell Cycle 12: 1385-1394, 2013.

135. Zhang H, Hao Y, Yang J, Zhou Y, Li J, Yin S, Sun C, Ma M, Huang Y and Xi JJ: Genome-wide functional screening of miR-23b as a pleiotropic modulator suppressing cancer metastasis. Nat Commun 2: 554, 2011.

136. Lin RL and Zhao LJ: Mechanistic basis and clinical relevance of the role of transforming growth factor- $\beta$ in cancer. Cancer Biol Med 12: 385-393, 2015.
137. Xiao F, Qiu H, Cui H, Ni X, Li J, Liao, W, Lu L and Ding K: MicroRNA-885-3p inhibits the growth of HT-29 colon cancer cell xenografts by disrupting angiogenesis via targeting BMPR1A and blocking BMP/Smad/Id1 signaling. Oncogene 34: 1968-1978, 2015.

138. Yamada N, Tsujimura N, Kumazaki M, Shinohara H, Taniguchi K, Nakagawa Y, Naoe T and Akao Y: Colorectal cancer cell-derived microvesicles containing microRNA-1246 promote angiogenesis by activating Smad 1/5/8 signaling elicited by PML down-regulation in endothelial cells. Biochim Biophys Acta 1839: 1256-1272, 2014.

139. Wang Y, Kim S and Kim IM: Regulation of metastasis by microRNAs in ovarian cancer. Front Oncol 4: 143, 2014.

140. Dwivedi SK, Mustafi SB, Mangala LS, Jiang D, Pradeep S, Rodriguez-Aguayo C, Ling H, Ivan C, Mukherjee P, Calin GA, et al: Therapeutic evaluation of microRNA-15a and microRNA-16 in ovarian cancer. Oncotarget 7: 15093-15104, 2016.

141. Nusrat O, Belotte J, Fletcher NM, Memaj I, Saed MG, Diamond MP and Saed GM: The role of angiogenesis in the persistence of chemoresistance in epithelial ovarian cancer. Reprod Sci 23: 1484-1492, 2016.

142. He J, Jing Y, Li W, Qian X, Xu Q, Li FS, Liu LZ, Jiang BH and Jiang Y: Roles and mechanism of miR-199a and miR-125b in tumor angiogenesis. PLoS One 8: e56647, 2013.

143. Wang W, Ren F, Wu Q, Jiang D, Li H and Shi H: MicroRNA-497 suppresses angiogenesis by targeting vascular endothelial growth factor a through the PI3K/AKT and MAPK/ERK pathways in ovarian cancer. Oncol Rep 32: 2127-2133, 2014.

144. Chan JK, Kiet TK, Blansit K, Ramasubbaiah R, Hilton JF, Kapp DS and Matei D: MiR-378 as a biomarker for response to anti-angiogenic treatment in ovarian cancer. Gynecol Oncol 133: $568-574,2014$

145. Lai Y, Zhang X, Zhang Z, Shu Y, Luo X, Yang Y, Wang X, Yang G, Li L and Feng Y: The microRNA-27a:ZBTB10-specificity protein pathway is involved in follicle stimulating hormone-induced VEGF, Cox 2 and survivin expression in ovarian epithelial cancer cells. Int J Oncol 42: 776-784, 2013.

146. Korpal M and Kang Y: The emerging role of miR-200 family of microRNAs in epithelial-mesenchymal transition and cancer metastasis. RNA Biol 5: 115-119, 2008.

147. Pecot C, Rupaimoole R, Yang D, Akbani R, Ivan C, Lum C, Wu S, Han HD, Shah MY, Rodriguez-Aguayo C, et al: Tumour angiogenesis regulation by the miR-200 family. Nat Commun 4: 2427, 2013.

148. Imam JS, Plyler JR, Bansal H, Prajapati S, Bansal S, Rebeles J, Chen HI, Chang YF, Panneerdoss S, Zoghi B, et al: Genomic loss of tumor suppressor miRNA-204 promotes cancer cell migration and invasion by activating AKT/mTOR/Rac1 signaling and actin reorganization. PLoS One 7: e52397, 2012.

149. Zhu AX, Duda DG, Sahani DV and Jain RK: HCC and angiogenesis: Possible targets and future directions. Nat Rev Clin Oncol 8: 292-301, 2011

150. Kota J, Chivukula RR, O'Donnell KA, Wentzel EA, Montgomery CL, Hwang HW, Chang TC, Vivekanandan P, Torbenson M, Clark KR, et al: Therapeutic microRNA delivery suppresses tumorigenesis in a murine liver cancer model. Cell 137: 1005-1017, 2009.

151. van Zandwijk N, Pavlakis N, Kao SC, Linton A, Boyer MJ, Clarke S, Huynh Y, Chrzanowska A, Fulham MJ, Bailey DL, et al: Safety and activity of microRNA-loaded minicells in patients with recurrent malignant pleural mesothelioma: A first-in-man, phase 1, open-label, dose-escalation study. Lancet Oncol 18: 1386-1396, 2017.

152. Kumar B, Yadav A, Lang J, Teknos TN and Kumar P: Dysregulation of microR NA-34a expression in head and neck squamous cell carcinoma promotes tumor growth and tumor angiogenesis. PLoS One 7: e37601, 2012.

153. Yu G, Yao W, Xiao W, Li H, Xu H and Lang B: MicroRNA-34a functions as an anti-metastatic microRNA and suppresses angiogenesis in bladder cancer by directly targeting CD44. J Exp Clin Cancer Res 33: 779, 2014.

154. Arunachalam G, Lakshmanan AP, Samuel SM, Triggle CR and Ding H: Molecular interplay between microRNA-34a and Sirtuin1 in hyperglycemia-mediated impaired angiogenesis in endothelial cells: Effects of metformin. J Pharmacol Exp Ther 356: 314-323, 2016.

155. Beg MS, Brenner AJ, Sachdev J, Borad M, Kang YK, Stoudemire J, Smith S, Bader AG, Kim S and Hong DS: Phase I study of MRX34, a liposomal miR-34a mimic, administered twice weekly in patients with advanced solid tumors. Invest New Drugs 35: 180-188, 2017. 